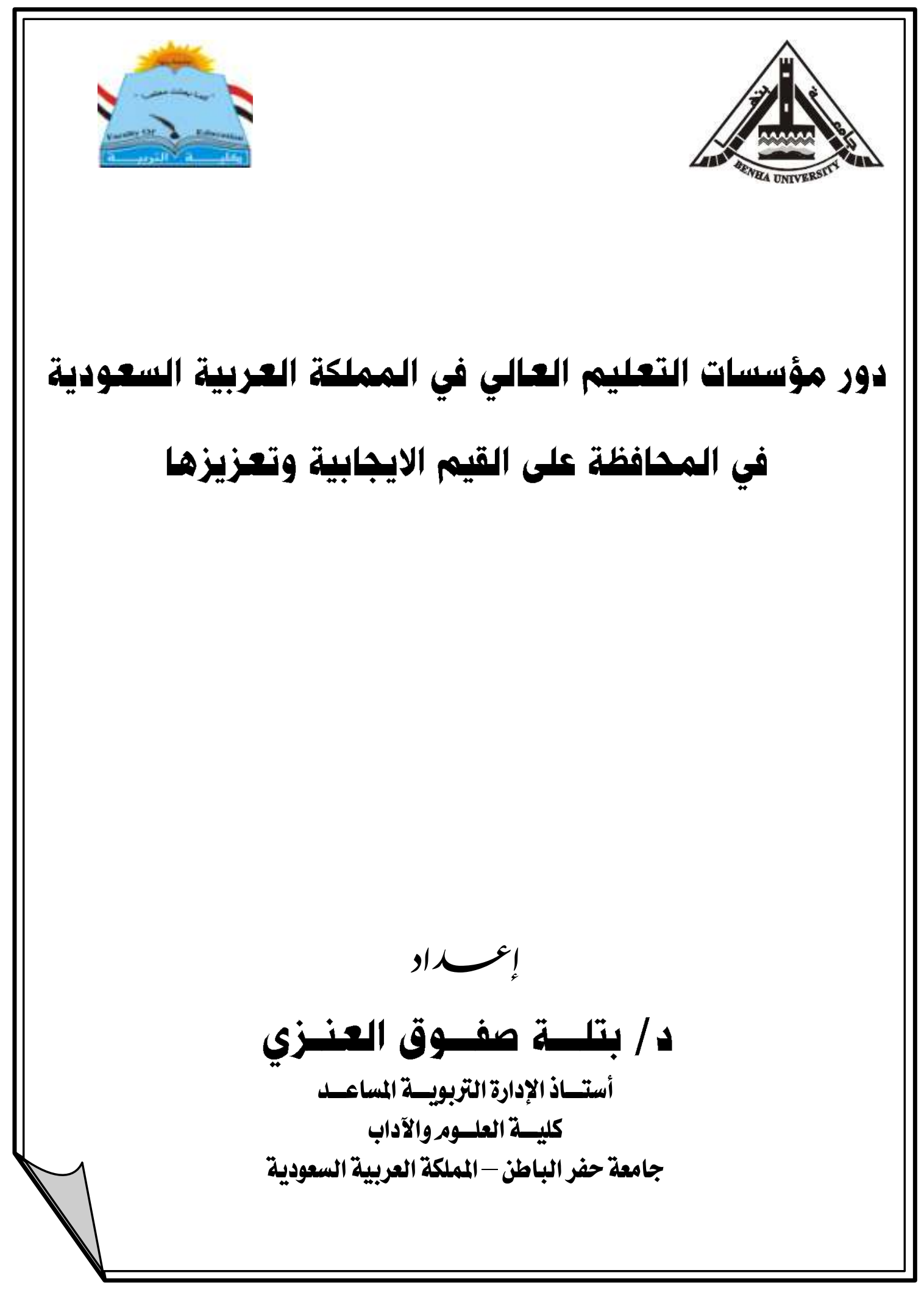




\title{
دور مؤسسات التعليم العالي في المسملكة العربية السعودية في المحافظة على القيم الايجابية وتعزيزها !
}

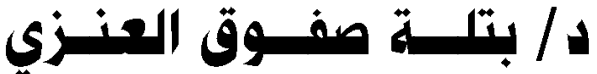

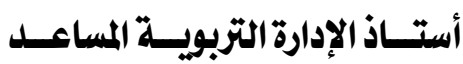

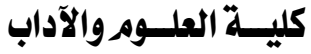 \\ جامعة حفر الباطن - المملكة العربية السعودية
}

\section{المسبتخل}

هدفت هذه الدراسة إلى الكثنف عن دور مؤسسات التعليم العالي في المملكــة العربيــة

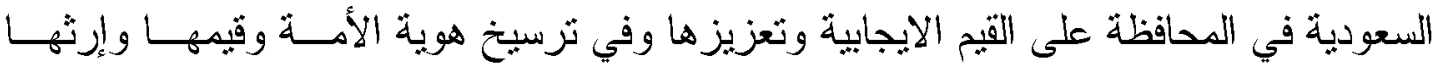

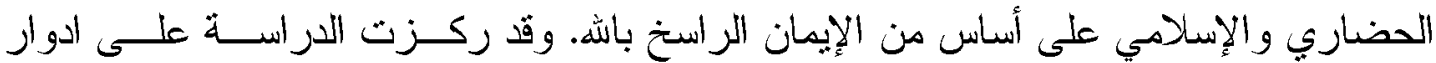
الجامعات ومؤسسات التعليم العالي في المملكة العربية السعودية من خلانل مجموعة من الإنة المجالات

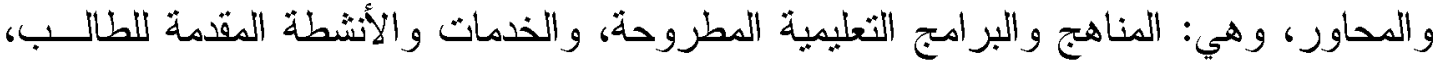
و التتشريعات التزبوية وأهداف الجامعة، والأستاذ الجامعي وأهدات الجامعة وسياساتها وفلسفنها.

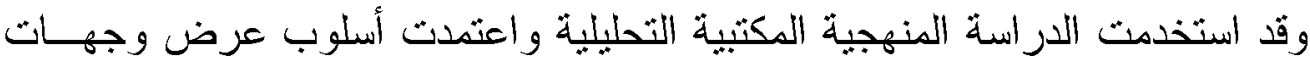

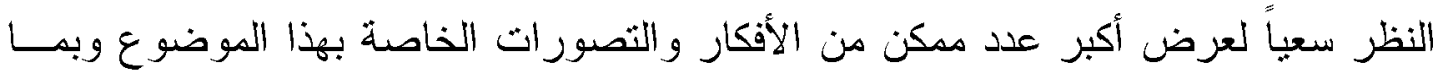
مكنتا من بناء وجهة نظرنا حوله.

وقد أنثارت الدراسة أن الجامعات وغير ها من مؤسسات التعليم العالي ثمثنـل بيئــة

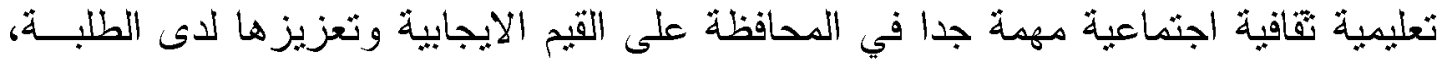

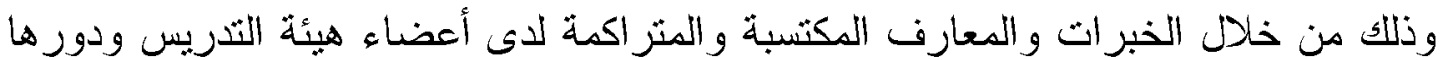

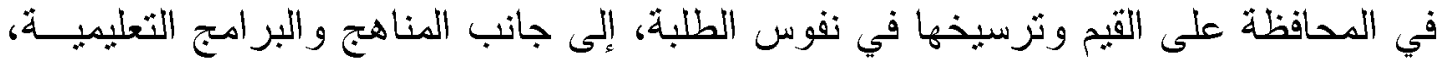

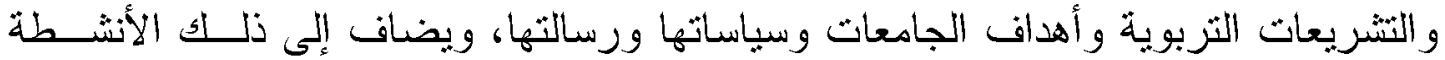
و الخدمات المقدمة للطلبة. وقد أظهرت معظم الدراسات في هذا المجال على الــدور الكيبـر

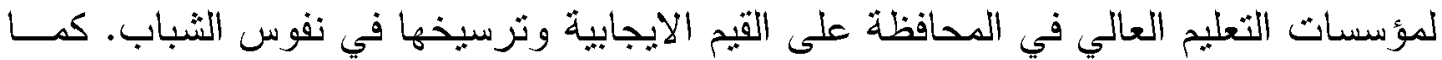

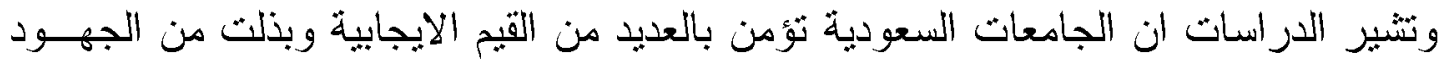
الكافية في المحافظة على نرسيخها لدى الثباب وتعزيز ها لديهم في حياتهم العلمبة والعملية.

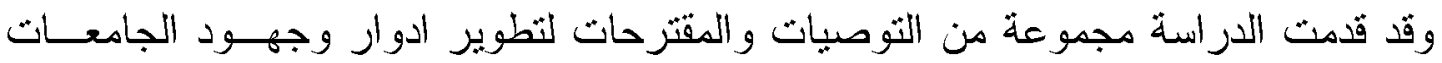
بثكل عام والجامعات السعودية بثكل خاص من اجل المحافظة على القيم الحقيقة وتعزيزها لدى منسوييها من الطلبة و العاملين. 
إن مؤسسات التحليم العالي ومن خلال الجامعات و الكليات و المعاهد وعهـادات شُهـؤون

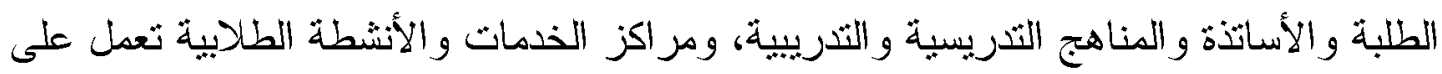

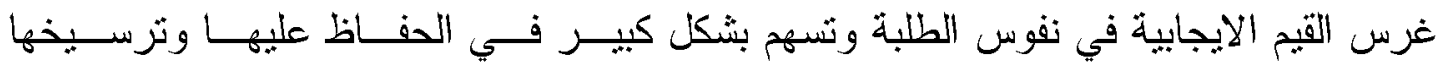

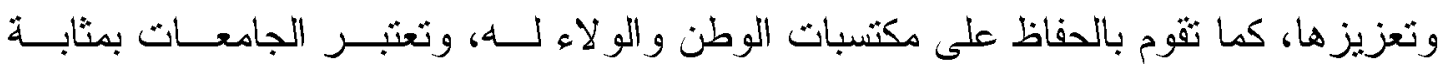

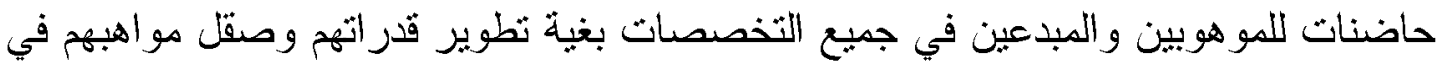

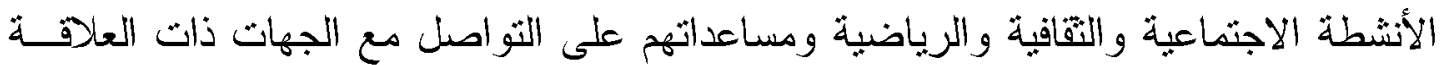

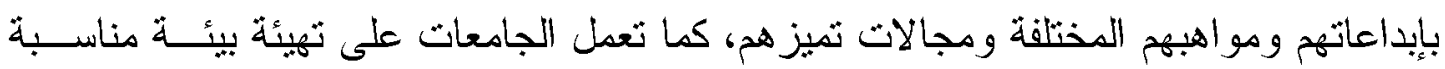

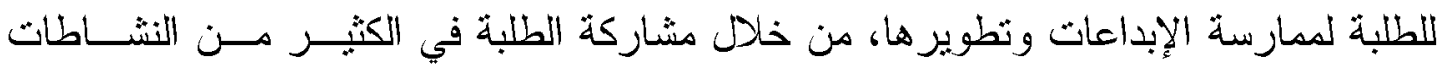

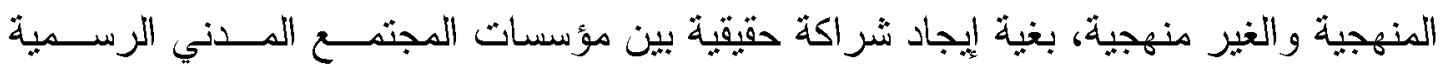

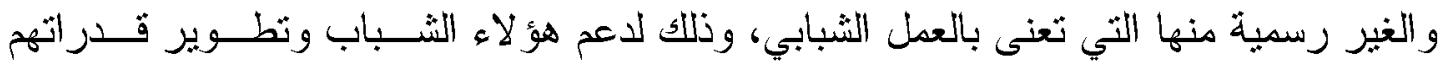

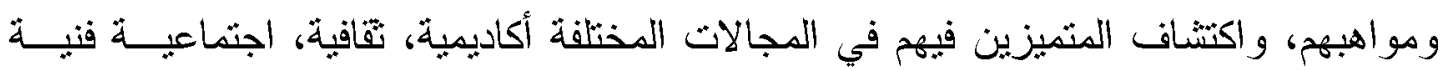

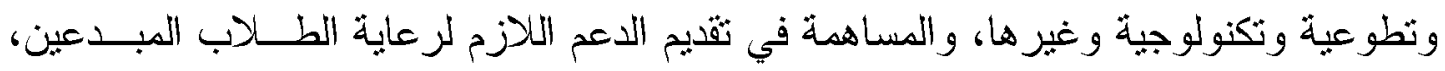

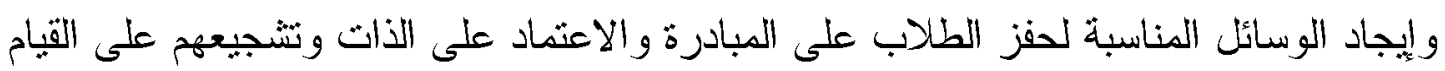

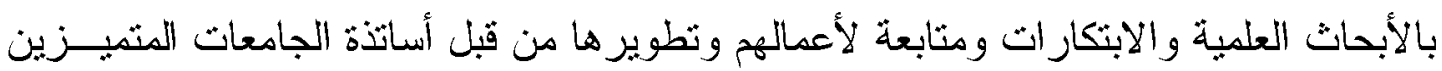

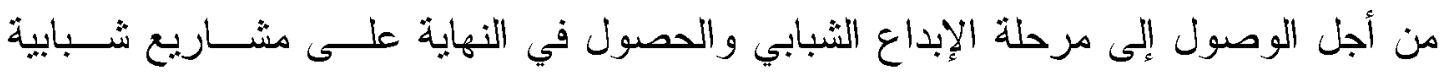

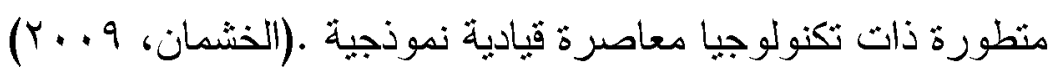

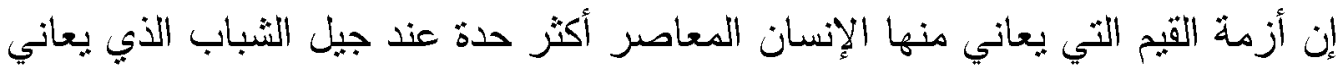

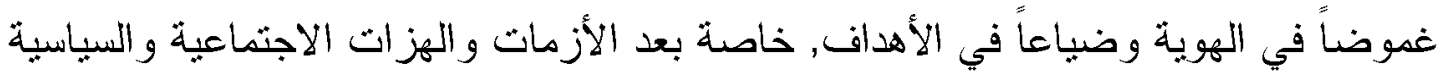

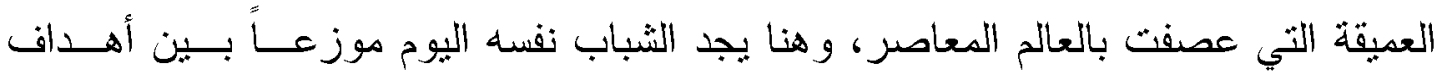

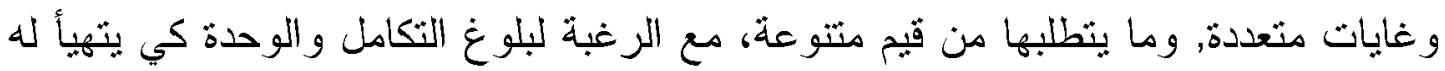

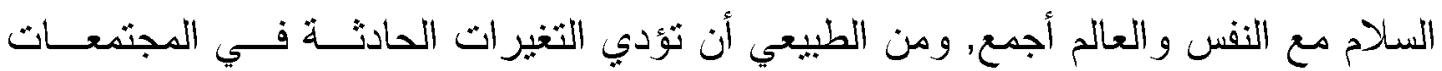

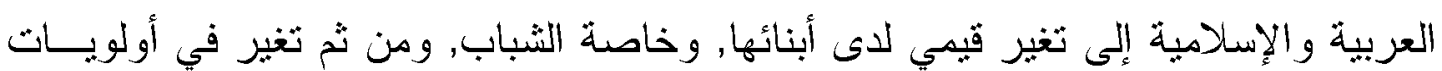

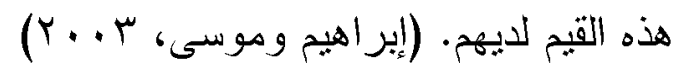

و الجامعة مؤسسة منميزة للتعليم تسهم في إعداد قادة المستقبل في مختلف مجــالات

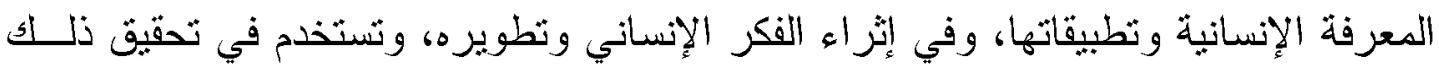

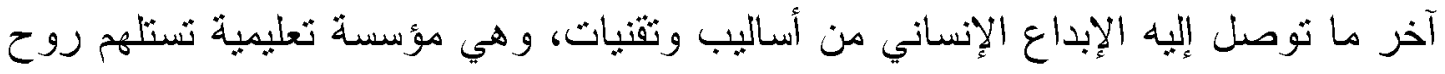
العصر وتستترف المستقبل، وتستتد على المعرفة الإنسانية والثقام العلمي والتقني في تأهيل 
وإعداد كو ادر بشرية في مختلف مجالات المعرفة، وهي إضافة أكاديمية إلى الوضع القائم في

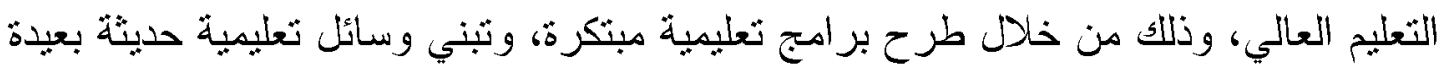
عن الثقليدية.

فتثقم المجتمعات وتخلفها بصفة عامة مرتبط بنظامها التربوبي و التعليمسي ارثباطـاً

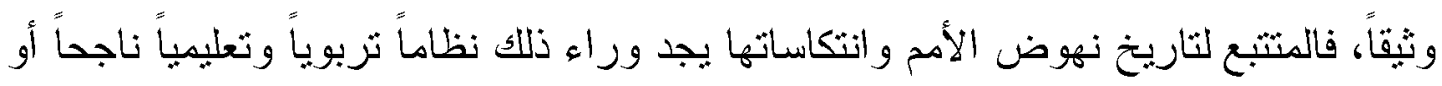

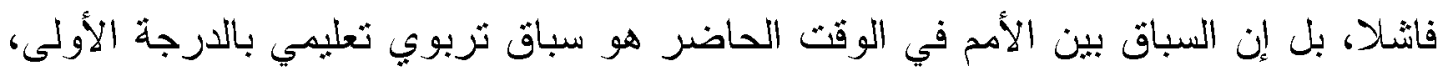

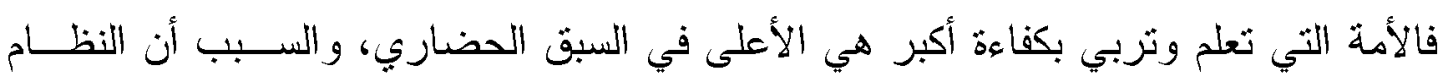

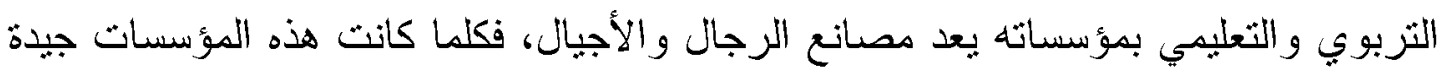

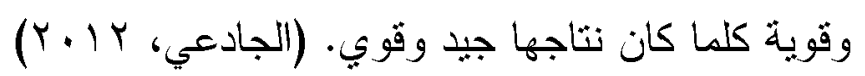

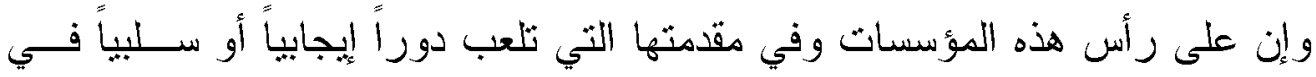

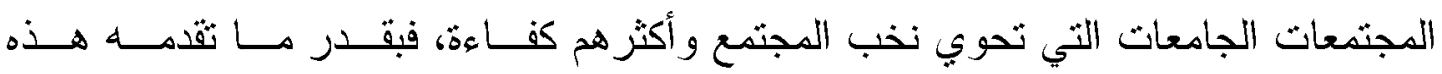

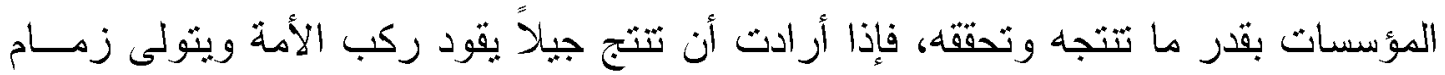

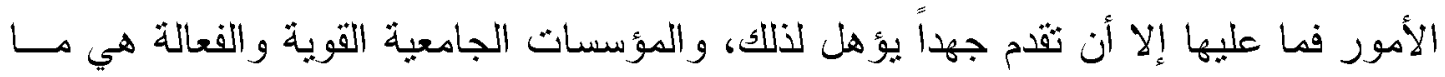

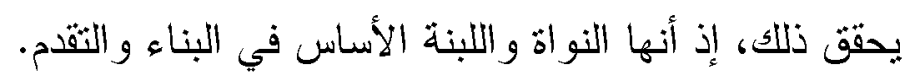

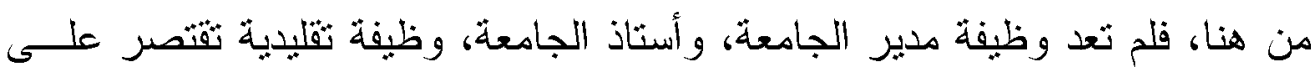

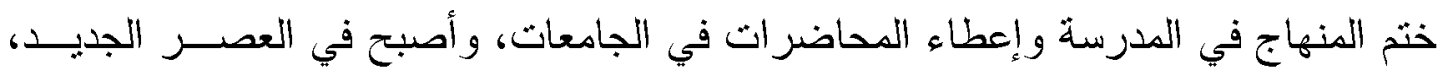

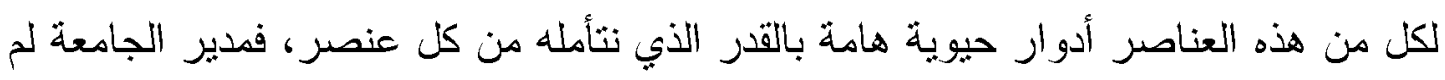

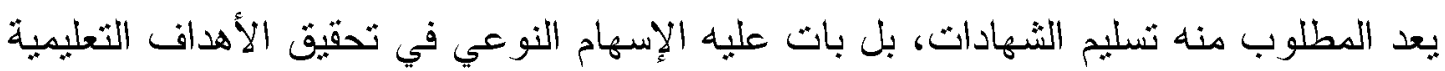

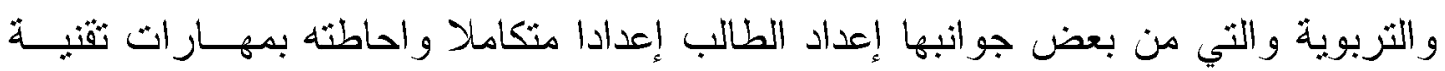

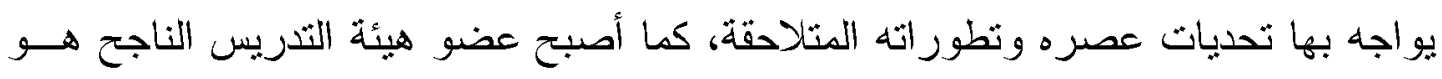

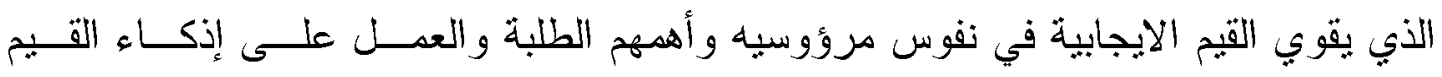

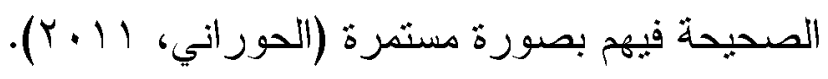

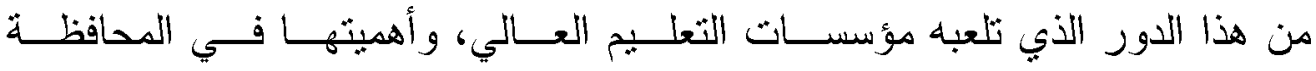

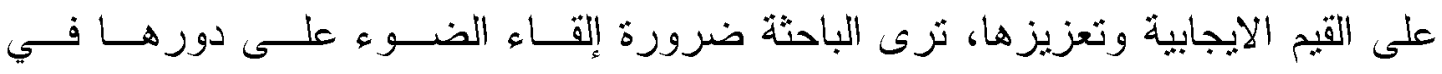

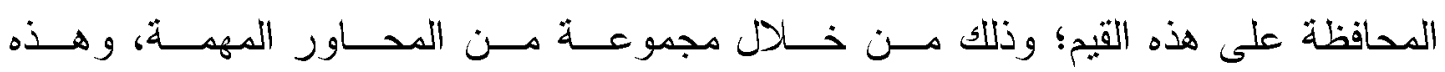

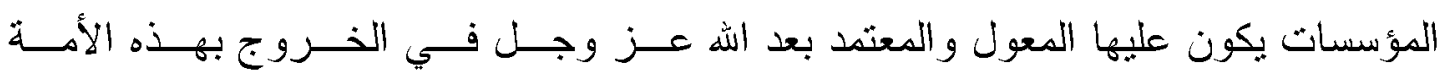

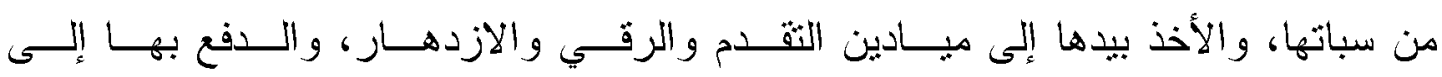
الأمام، وتحقيق أهدات الأمة ورفعة مكانتها بين الأمم الأخرى. 


\section{مشكاسلة الدراسيسة:}

يعاني المجنمع الإسلامي من قصور في تأكيد ذانه وهوينه النقافية إلى جانب معاناته من قصور في الوسائل الحضارية المادية، و هذا يعود في دعظمه إلى معاناته الحقبقة.

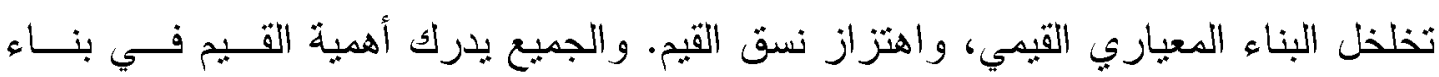

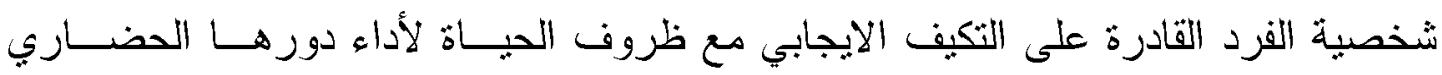

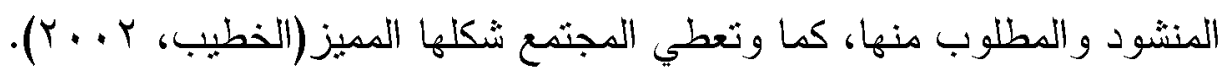

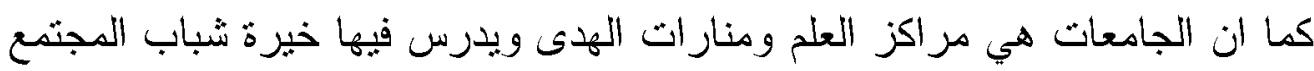

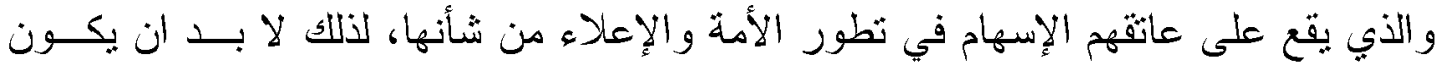

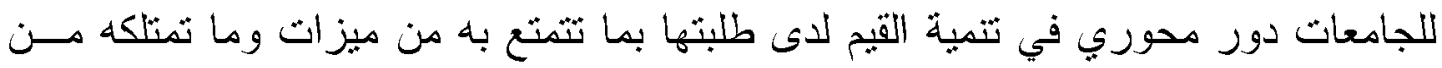

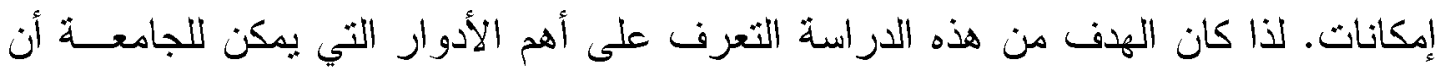

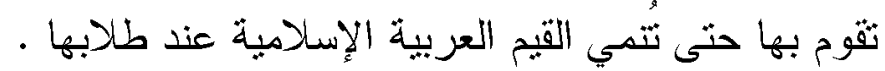

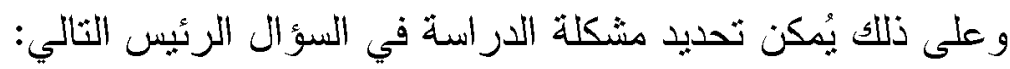

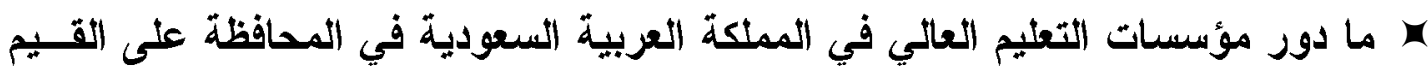

\section{الايجابية وتعزيزها؟}

\section{وينبثق عنه مجموعة من الأسئلة الفرعية، وهي:}

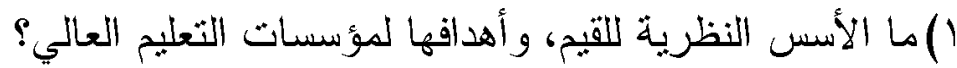

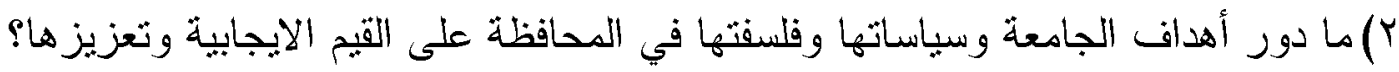
كام) ما دور التثريعات الثربوية في المحافظة على القيم الايجابية وتعزيزها؟

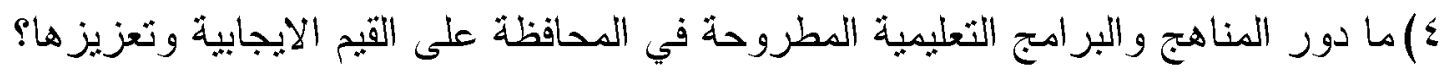
0) ما دور الأستاذ الجامعي في المحافظة على القيم الايجابية وتعزيز ها؟

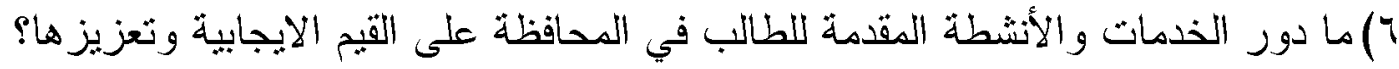

\section{أهـــاف الدراسبـة:}

تهذف الدراسة على المستوى العلمي إلى إلقاء الضوء علــى دور مؤسســات التعلــيم

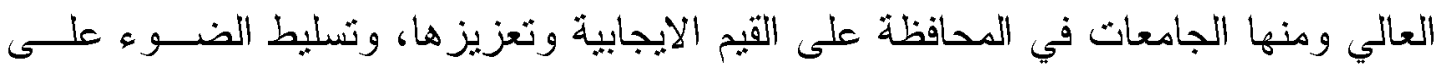

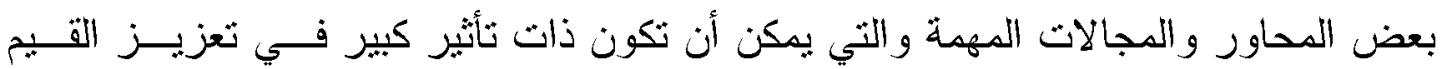

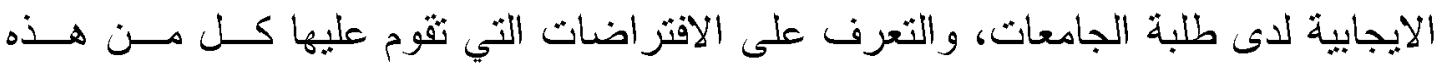

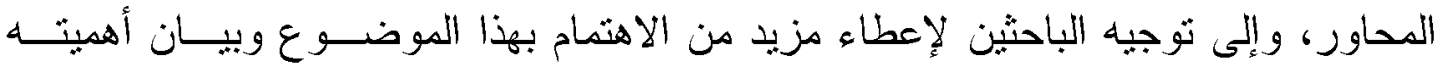
و انعكاساته على العلاقة بين المؤسسات التعليمية والمجنمعية. 


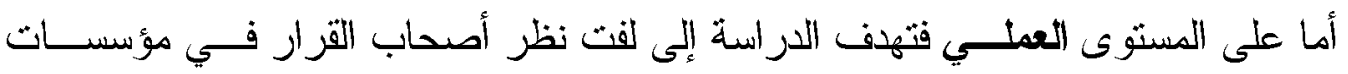
الثعليم العالي لأهمية إيلاء الاهثمام لتتمية القيم الايجايبة عند طلبة الجامعات، ودور ذلك في نتمية

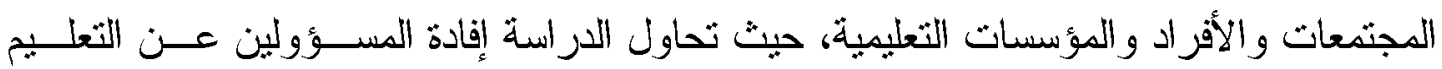
العالي في التعرف على الجوانب المختلفة لدذل حديث ثبت نجاحه في تطويز وتثبز التعليم فــي مؤسسات النعليم العالي. ومن اجل ذلك حاولت الاراسة تحقيق الأهداف الفرعية التالية:

$$
\text { توضيح مفهوم القيم وأهدافها. }
$$

توضيح دور مؤسسات الثعليم العالي في المحافظة على القيم الايجابية لدى الثـــباب

$$
\text { وتعزيزها. }
$$

\section{أهميــة الدراســة}

تتبع أهمية هذه الاراسة من أهية الموضوع الذي بحثثه وهو دور الجامعسات فــي

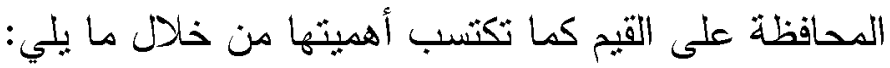

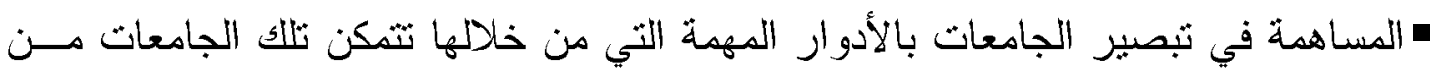
تتمية القيم عند طلبتها.

- المساهمة في تطوير نموذج للتحليم الجامعي تتكامل فيه ادوار العاملين في الجامعة لتحقيق وظائفها ورسالتها.

- النعرف على المسؤولية الفردية لكل من بعمل في الجامعة مهما كانت طييعة عمله في تنمية

$$
\text { القيم لدى الطلبة. }
$$

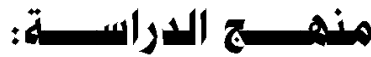

اتبعت الدراسة الحالية المنهج الوصفي التحليلي، وذلك لملاعهتــه لطيبعـة الدراســة

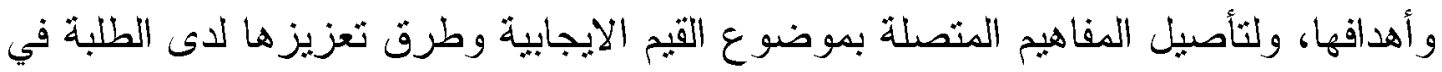

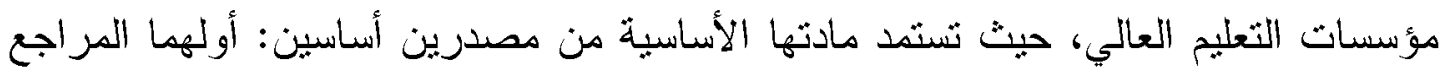

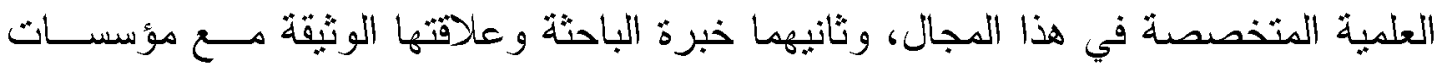

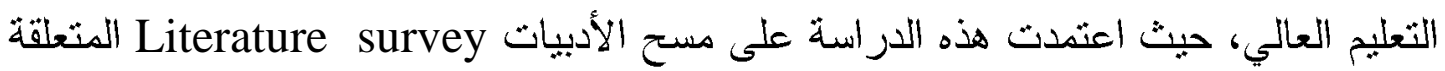

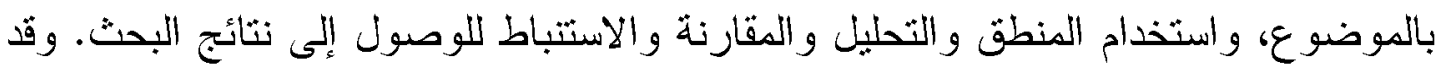
ساعدت هذه المنهجية في الإجابة عن نساؤلات الدراسة. 


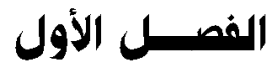

\section{مفهوم القيم والأهداف الرئيسية لمؤسسات التعليم العالي \\ لو

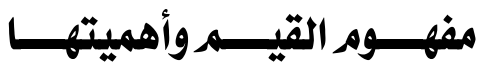

من الواضح أن الثتربعات الرسمية المتعلقة بأهداف التعليم الجـامعي علـى المســنويات

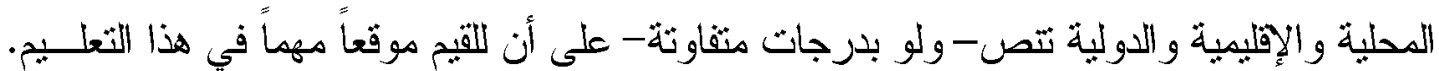

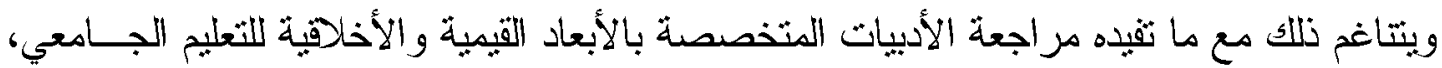
سواءً الكتب المنهجية، أو بحوث الدوريات العلمية وأعمال المؤتمرات ووثائق الجامعــات، حبــث

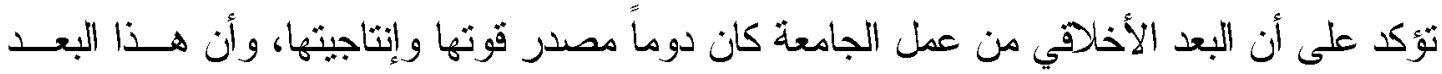
نفسه أصبح في العقود الأخيرة مصدر ضعفها وتثهورها. (Johnston, 2000) كنلك بمكن التأكبد

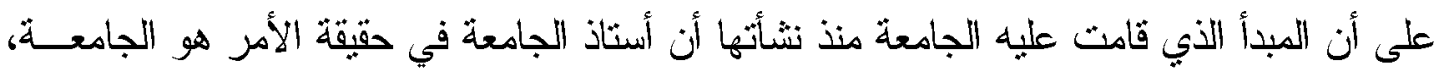

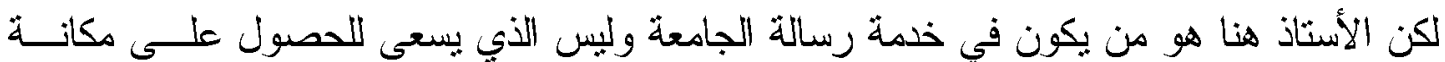
خاصة لنفسه أو لتحقيق منفعة ذانية. (O'Brain, 1998)

وقد تز ايد الاهتمام بدراسة القيم خلال العقود الأخيرة من قبل المتخصصين في كافــة

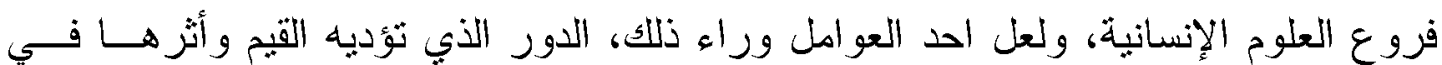

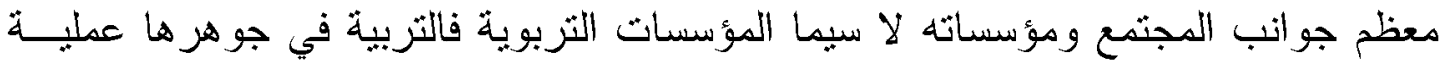

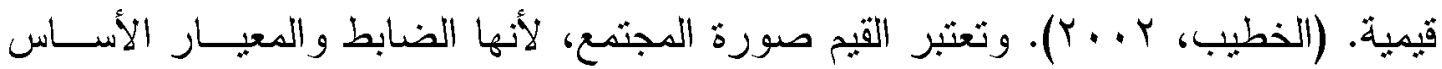
للسلوك الفردي والجماعي، و المجتمع في عموده لا بتكون دون وجود هذا البناء المعيــاري

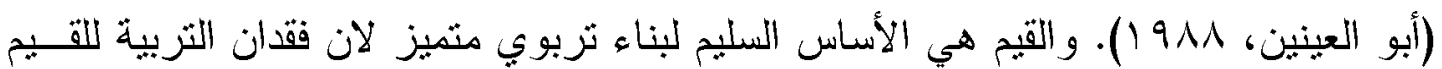
الني تننى عليها الثخصية، يققدها روحها بل ان الأهدات التربوية والغايات والاستراتيجيات

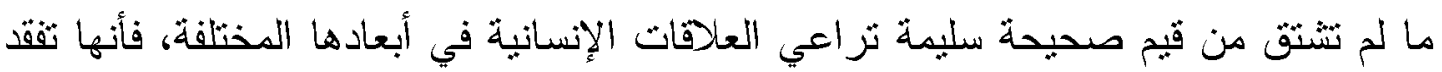
أهيثها وقيمنها. وقد يكون من الصعب الاتفاق على مفهوم محدد للقيمة - على الرغم مـن

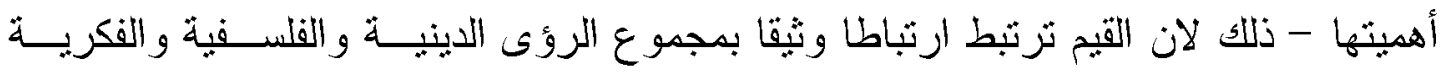

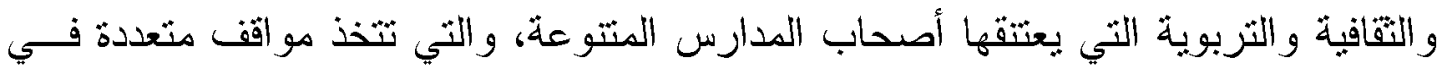
نظرتها للمعرفة وللإنسان وللوجود، وبمقدار هذا الاختلاف وعمق هذا التغاير ، تتعدد الرؤى وتختلف زوايا النظر عند ثتاول مصطلح القيم أو دراسة موضوعاتها. (الجلاد، 999 1). 


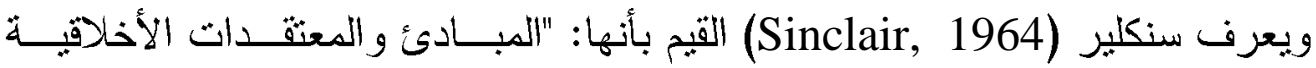

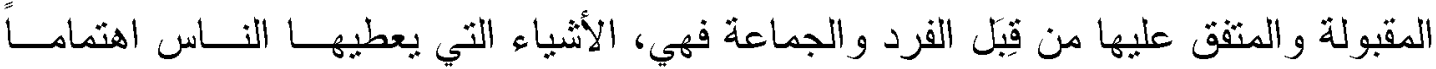

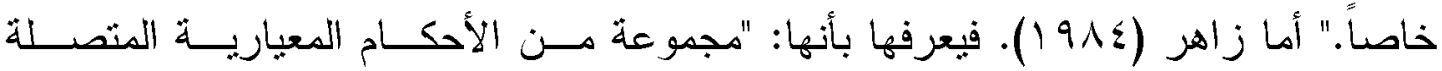

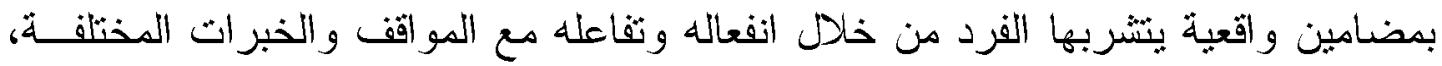

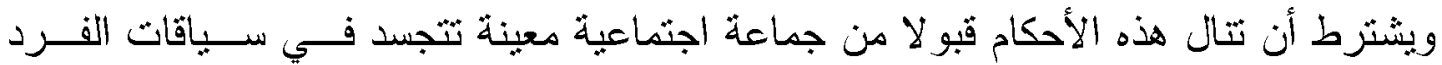

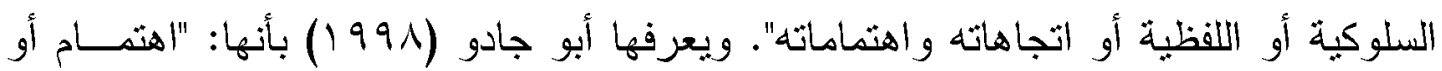

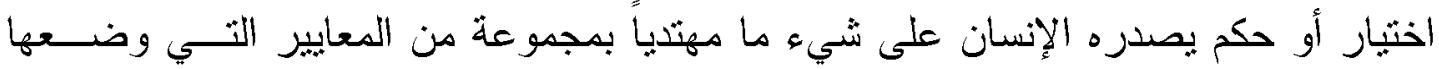

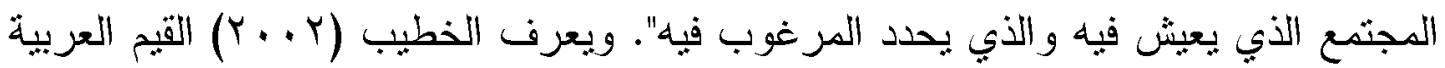

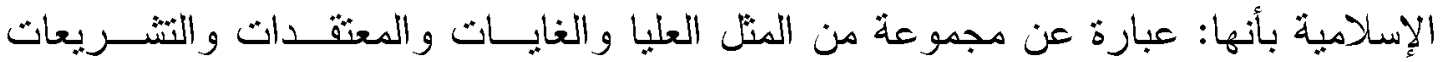

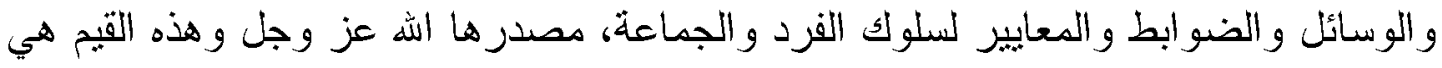

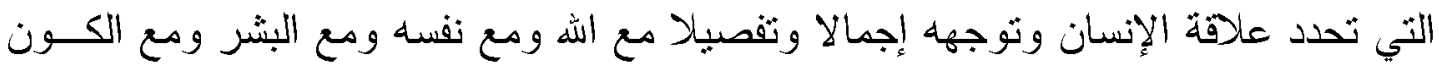
وتتضمن هذه القيم غايات ووسائل.

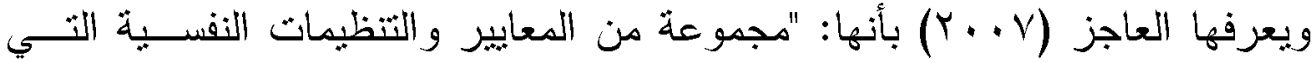

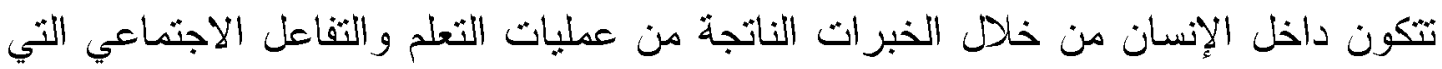

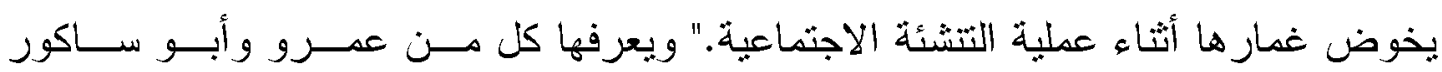

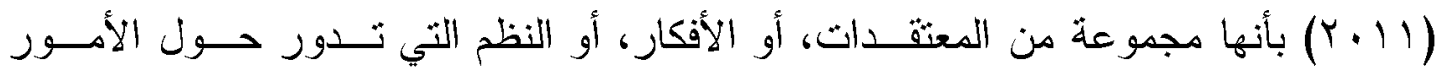

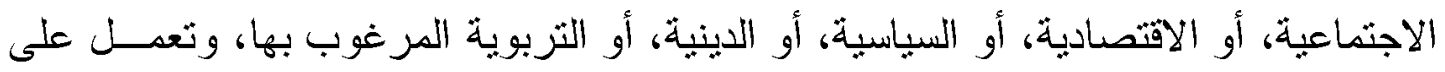

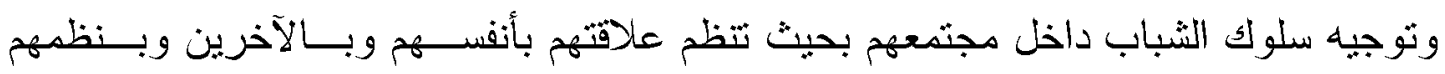

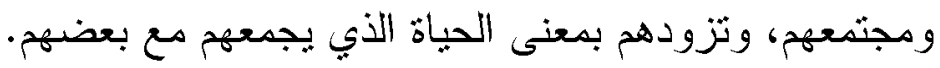

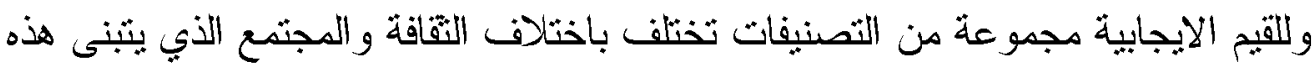

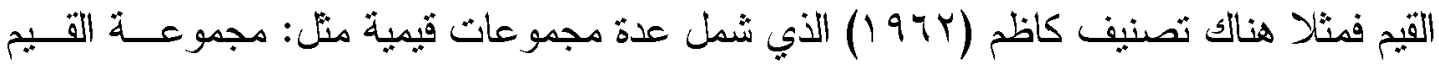
الأخلافية, ومجموعة القيم الذانية, ومجموعة قيم الأمن, ومجموعة القيم الجســـانية, ومجموعــة

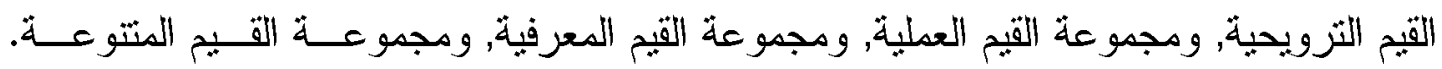

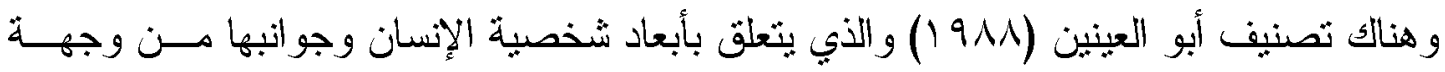

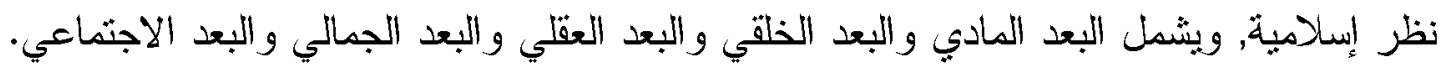

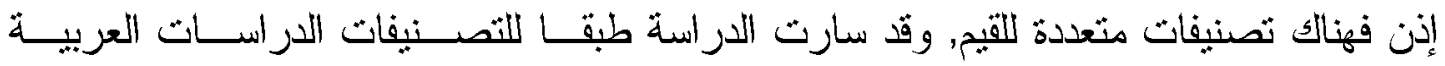

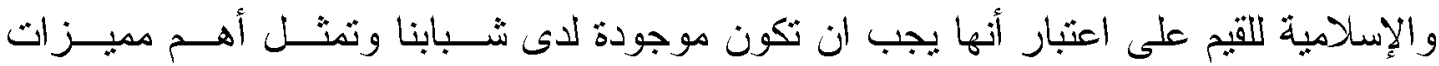

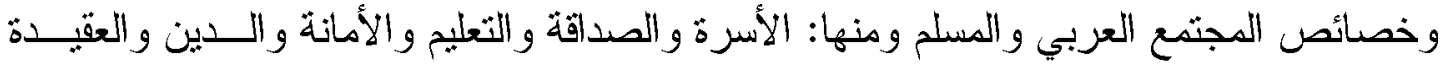


ومساعدة الآخرين والعطف والثقة والعمل وطاعة ولى الأمر والاستقلال الذاتي والعهـل الجــاد

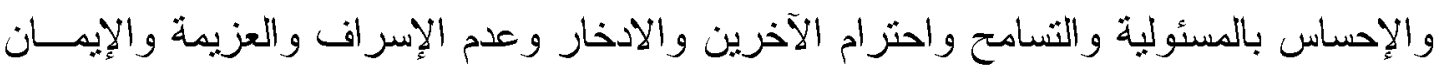

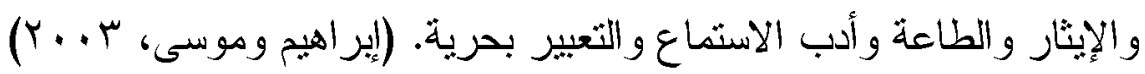

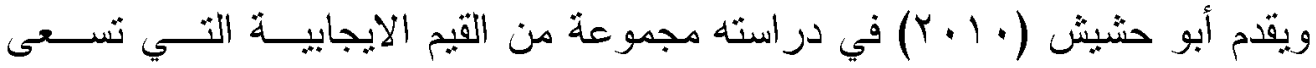
مؤسسات التعليم العالي في الوطن العربي إلى تتمينها وتدعيمها لاى طلبنها ومنها: تعزيز قيم التسامح.

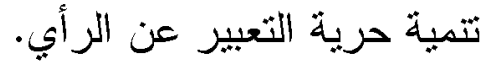

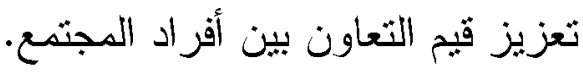

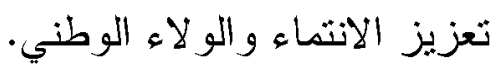
تعزيز الثقة بالنفس. تتمبة قدرة الإنسان على التمسك بحقه. هإبراز دور مؤسسات المجتمع المدني في التتمبة الاجنماعبة.

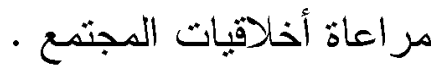

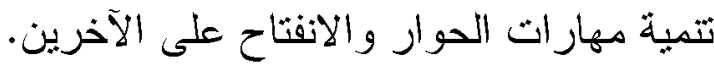
زيادة القدرة على النقة الإيجابي. تنمية القدرة على إصدار الأحكام الموضو عية على الإبلى الأثياء دون تحيز.

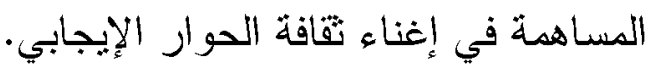
تعزيز الإدراك بقيمة الحرية الثخصبة واستقلالية الذات. هالتأكيد على ضرورة مساعدة أفر اد المجتمع في تلبية حاجاتهم. هضامن أفر اد المجتمع في حل المشكلات و التحديات.

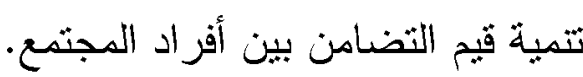
تعزيز مبدأ نبذ العنف و الثمييز بكل أنكاله. هثقير قيمة العمل الجماعي والانخر اط فيه. الالهنمام بقضابا ذوي الحاجات الخاصة. إدر الك الحقوق وممارسنها و الدفاع عنها.

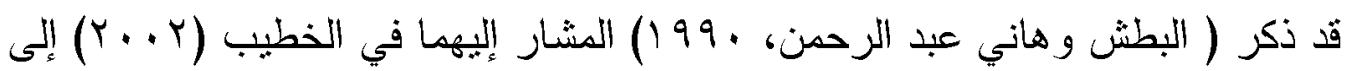
وجود عدة وظائف للقيم وهي: 
القيم تعد معيارا لأنها توجه السلوك الصادر عن الأفراد إلى جهة معينــة ومدـددة

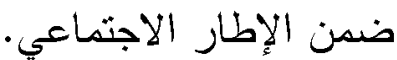
تجعل الفرد أكثر مبلا وتفضيلا لايدولوجيا سباسية أو دينية أو اجتماعبة أو اقتصادية معينة دون غير ها.

تحدد الطريقة الني بعرض بها الفرد نفسه للآخرين فهي معايير لتقديم التعزيز والثناء و اللوم الذبي بتلقاه الفرد من نفسه أو الآخرين. تعد أساساً لإجر اء المقارنات بين المجثمعات المختلفة.

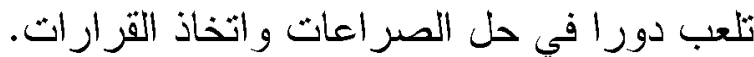

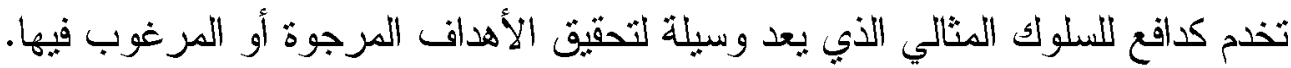
تساعد الفرد على النكيف.

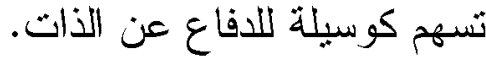

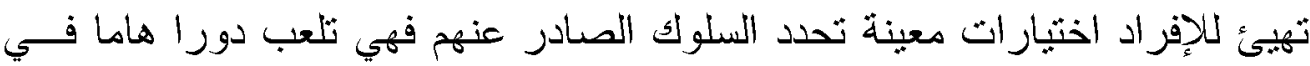

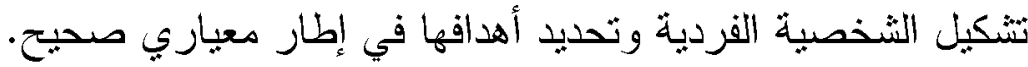

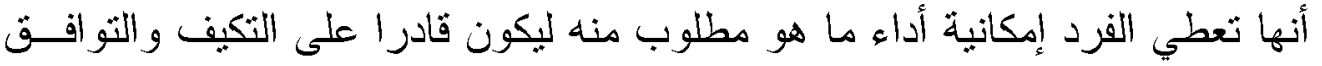
بصورة ايجابية. تحقق للفرد الإحساس بالأمان فهو يستعين بها على مواجهة ضعف نفسه والتحـديات التي تو اجهة في حياته. تعطي للفرد فرصة للتعبير عن نفسه وتأكيد ذاته.

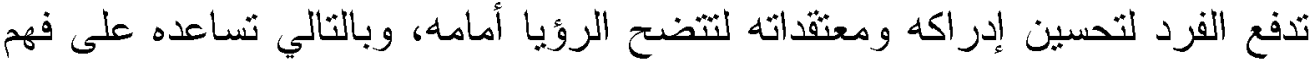
العالم من حوله وتوسع إطاره المرجعي في فهم حياته و علاقاته. تعمل على إصلاح الفرد نفسيا وخلقيا ونوجهه نحو الإحسان و الخير و الو اجب.

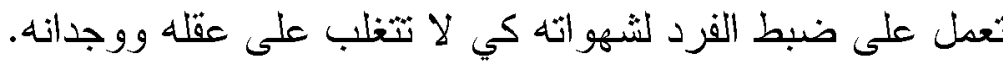
تحفظ على المجتمع تماسكه فتحدد له أهداف حياته ومثلكه العليا ومبادئه الثابتة. تساعد المجتمع على مواجهة التغيزات التي تحدث فيه بتحديدها الاختيارات الصديحة وذللك يسهل على الناس حياتهم ويحفظ للمجتمع استقراره وكيانه في إطار موحد.

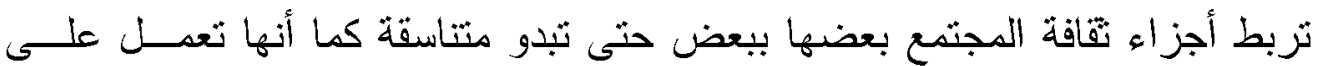
إعطاء النظم الاجتماعية أساسا عقلبا بصبح عقيدة في ذهن أعضاء أعضاء المجتمع المنتمين

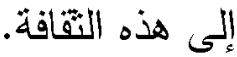


تقي المجتمع من الأنانية المفرطة والنزعات والثهوات الطائنة، فالقيم و المبادئ في

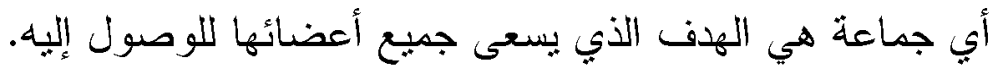

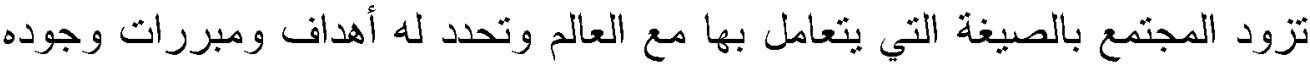
وبالثالي يسلك في ضوئها وتحدد للأفر اد سلوكياتهم.

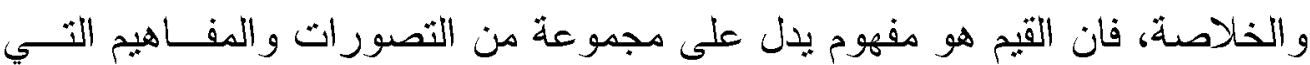

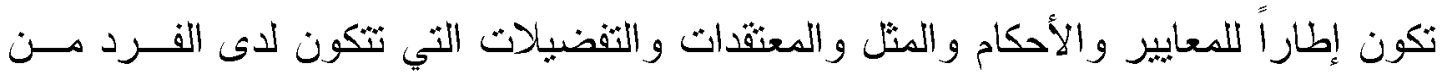
خلال تفاعله مع المو اقف والخبرات الفردية والاجنماعية، بحيث ثمكنه من اختيــار أهــاف

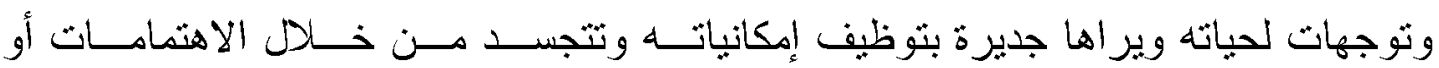

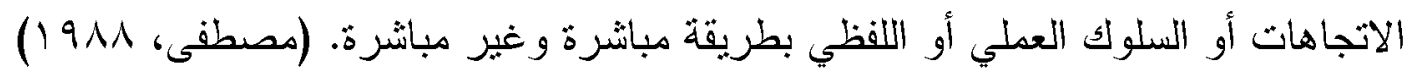

\section{المبحث الثاني}

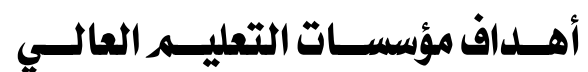

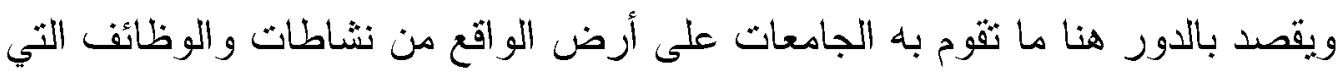

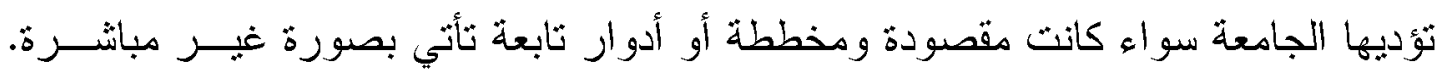

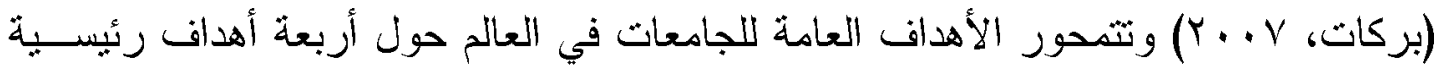
بمكن إيجاز ها فيما بلي: الئي ه النزويد بالمعرفة و الحقائق ونقلها وتعليمها للطلاب.

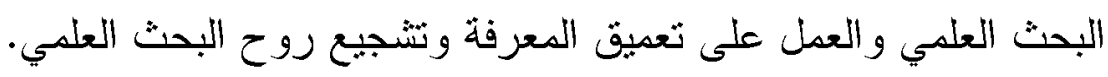

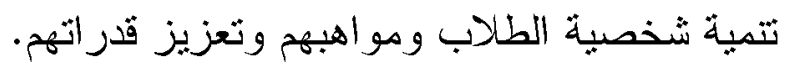

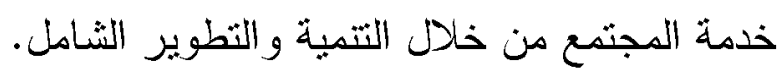

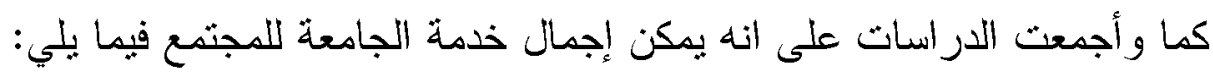

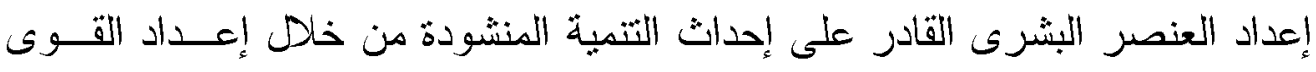

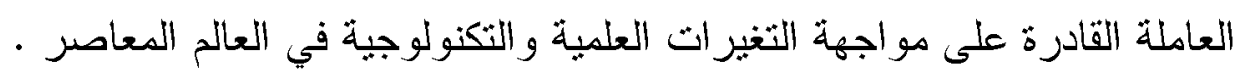

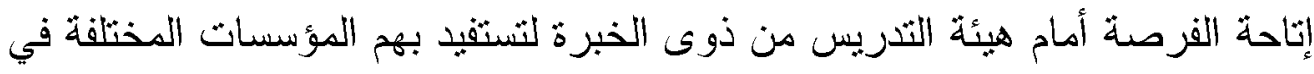

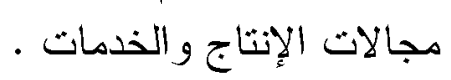

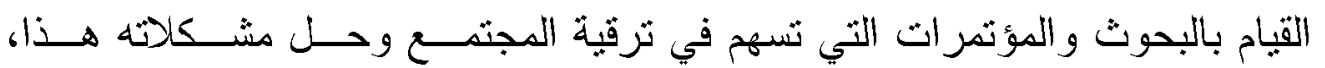

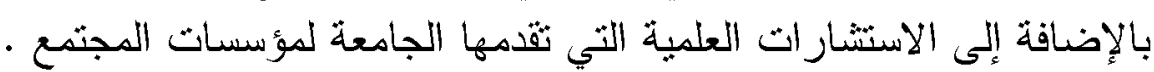

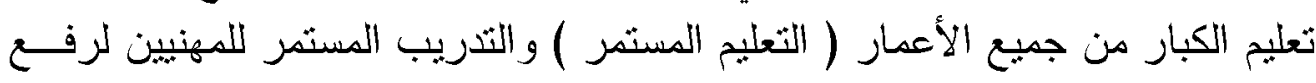

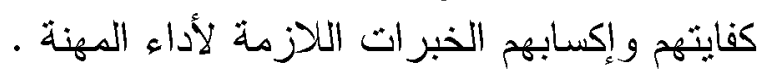




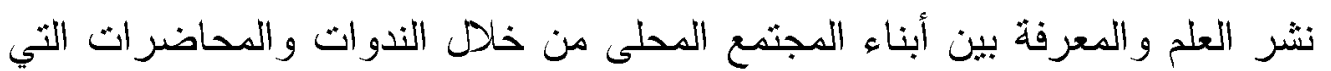

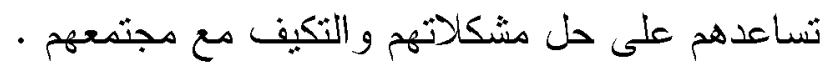

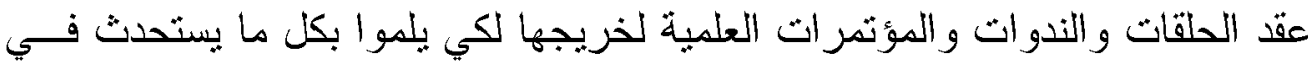
مجالات تخصصهم ومعالجة المشكلات التي تو اجهوم في الحياة العلمية .

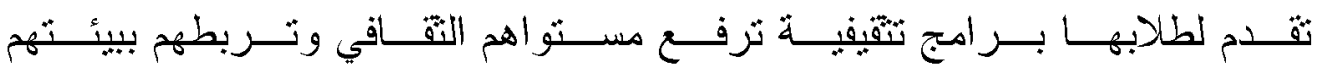

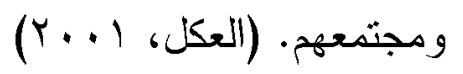

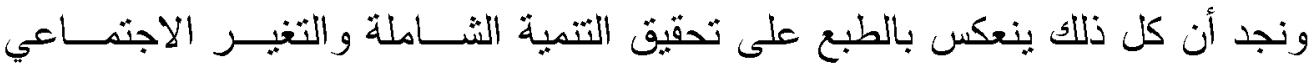
المنشود وتقوية روح المبادرة و المثاركة ونوثيق العلاقات الإنسانية ومعرفة الأساليب الفنية الإنية

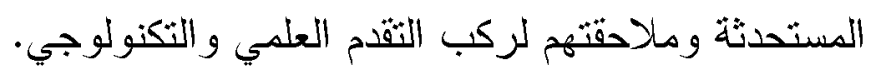

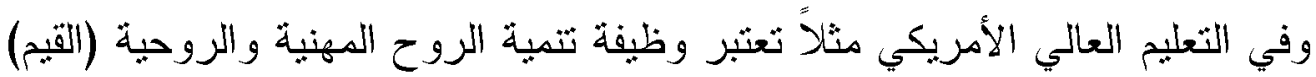

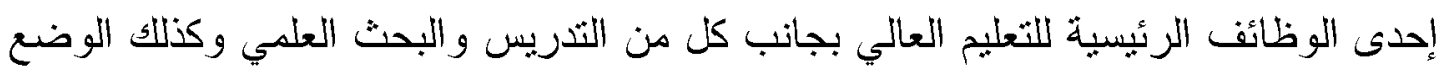

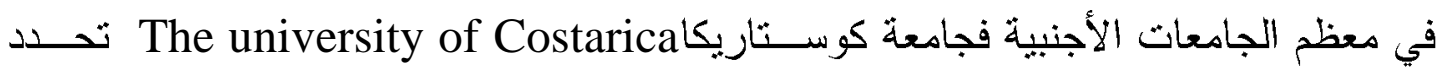
وظبفتها الأساسبة في تقديم المعرفة والاستجابة للاحتباجات الفعالة والأساسية لتنمية المجتمع

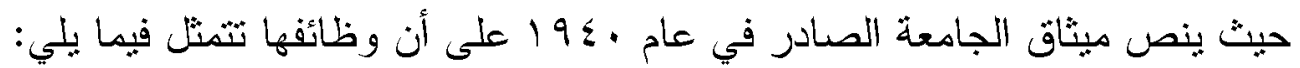

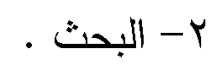

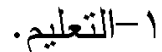

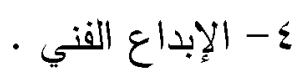

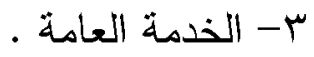

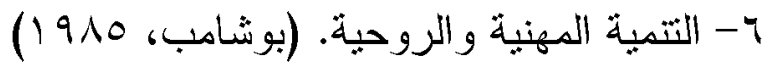

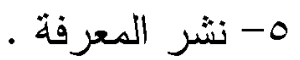

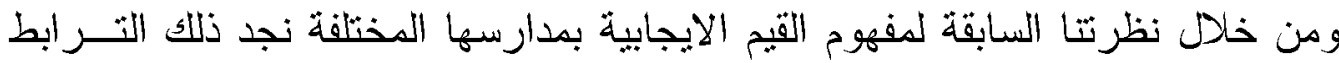

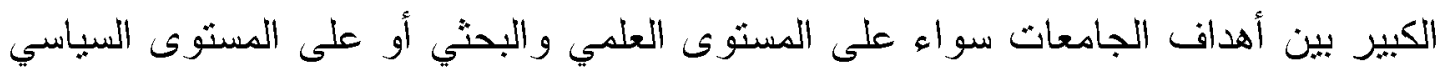
و الاجتماعي و الثقافي والتي ترتبط بدفهوم القبم و المحافظة عليها وتعزيز ها.

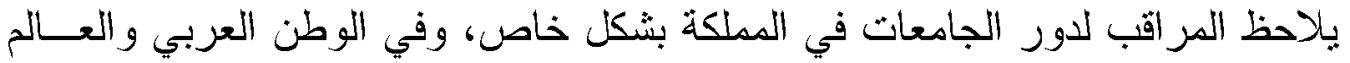

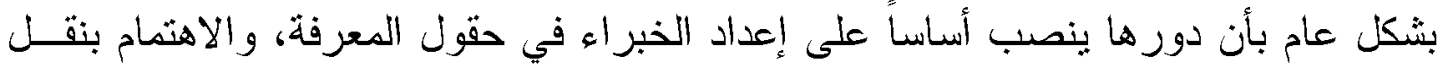

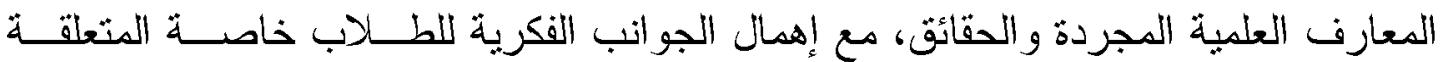
بتتمية إحساسه بالانتماء، وتزويده بالقيه، ونوعبة المخاطر التي تحيط بها، وإعداده لمجابهــة التحديات الني تهدد وطنه و أمنه.

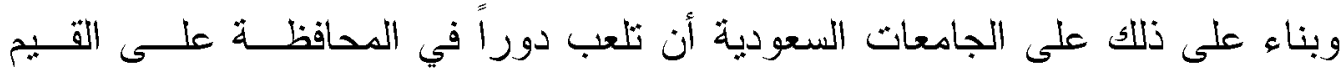
وتعزيزها، و العمل على خلق جيل قادر على المشاركة في القضايا كافة القضــايا الوطنيـــة.

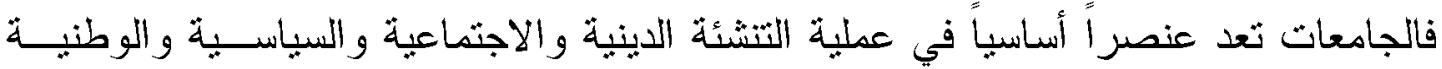




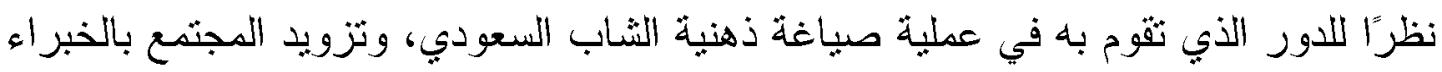

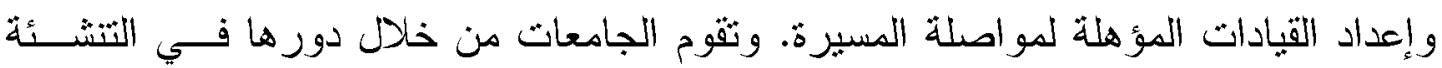

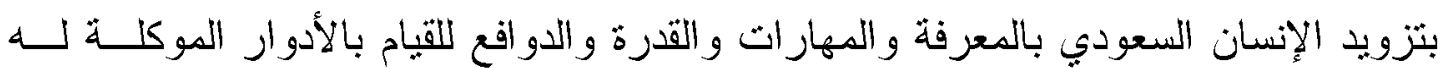

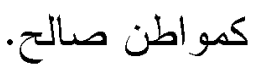

وقد أثنارت العديد من الدراسات بان مؤسسات التعليم العالي يمكن ان يكون لهـا دور

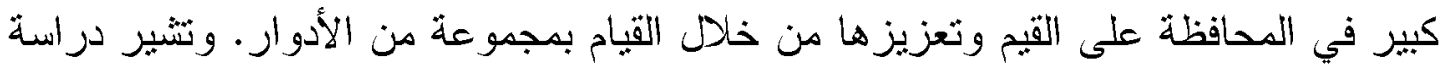

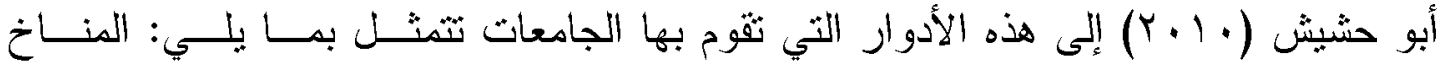
التنظيمي، والمقررات الدراسبة والأستاذ الجامعي والأنثطة الجامعية.

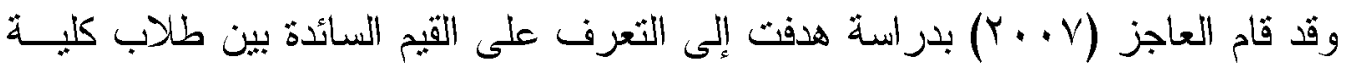

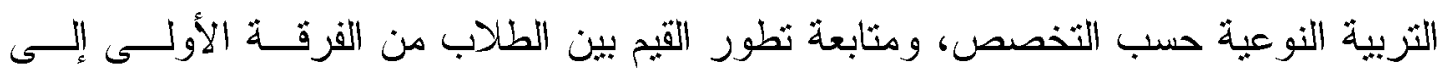

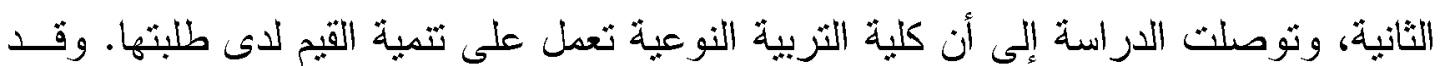

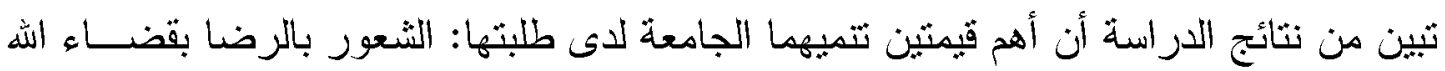

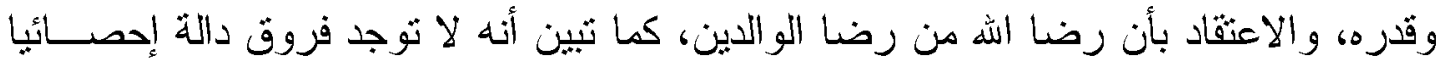

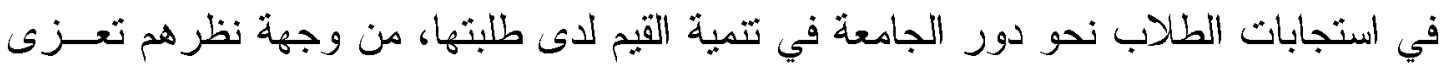

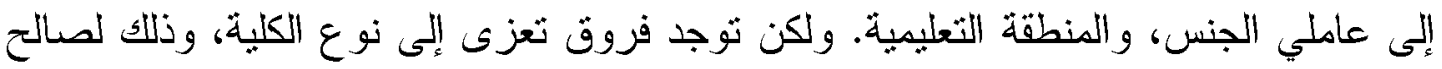

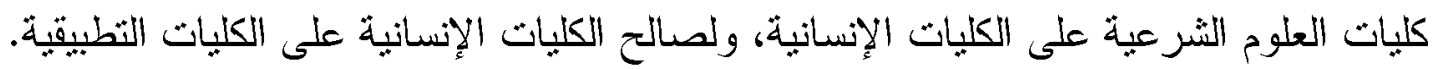

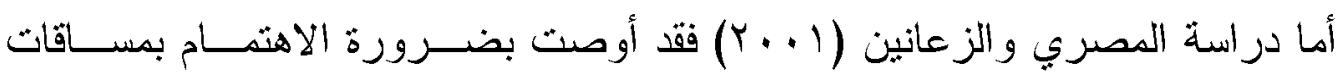

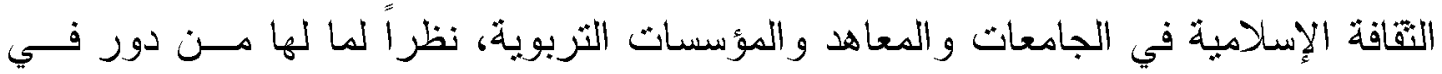

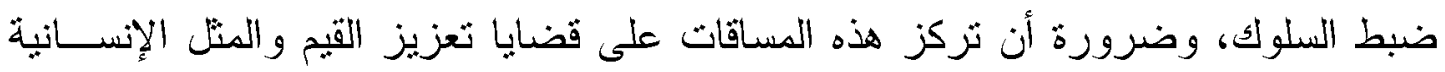

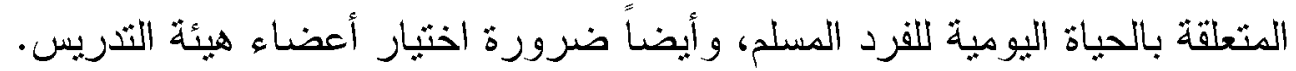

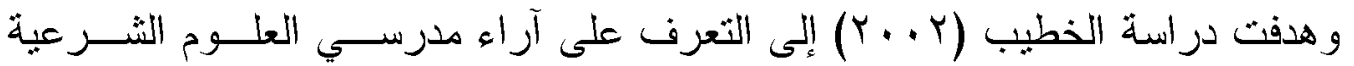

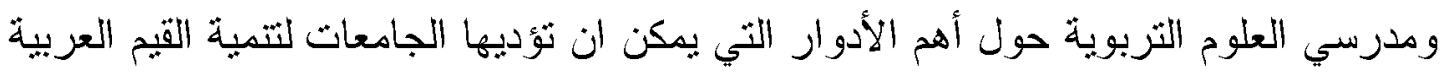

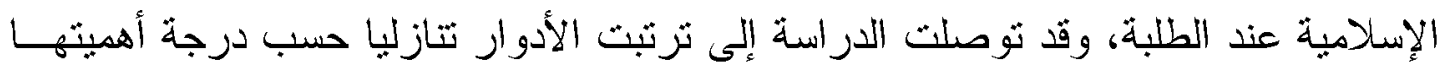

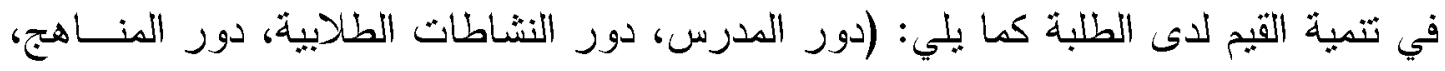

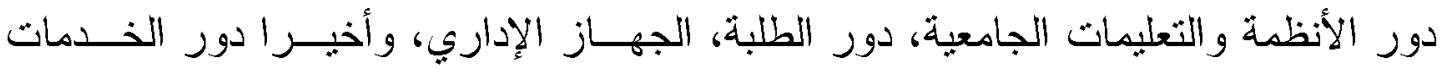

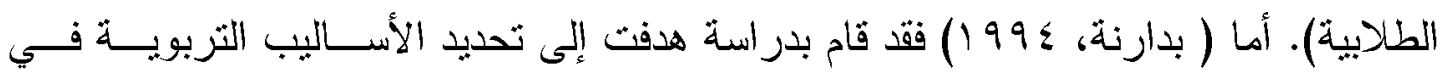

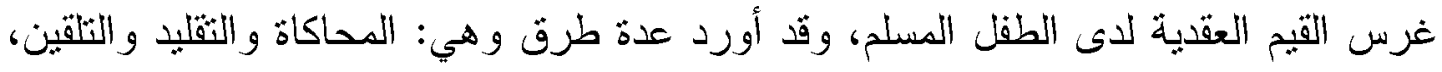
و القدوة، وضرب المثل، الحوار، و الثر غيب و الترهيب، و الو عظ، و القصة، و التأمل و التفكير. 
ولقد سعت دراسة (العلاونة وآخرون، (999) إلى تطوير مقياس للقيم الاجتماعبة في

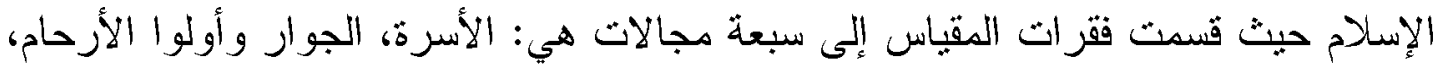

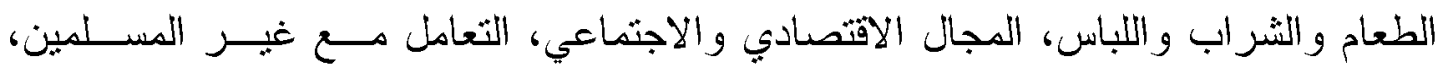
الأمر اض الاجنماعية، مجال المبادئ العامة.

وينحدد دور مؤسسات التعليم العالي في المحافظة على القيم الايجابية وتعزيزهـا، مـنـ

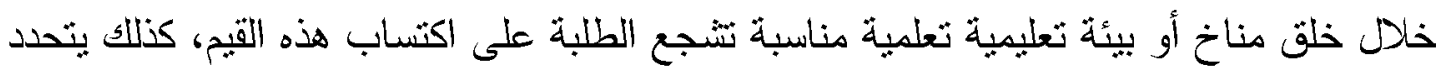

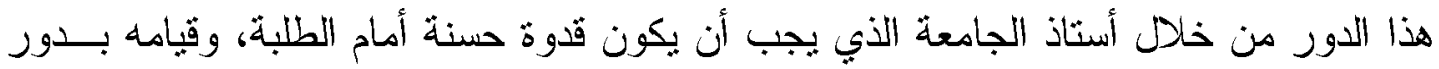

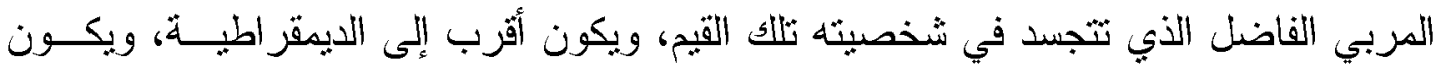

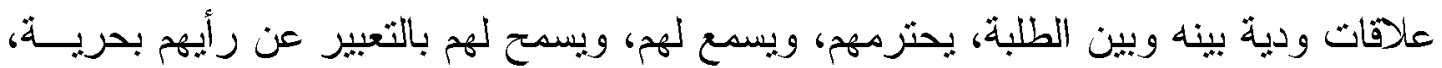

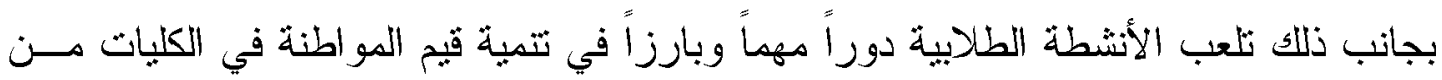
خلال تجسبد روح التعاون و العمل النطوعي والتسامح و العدل والمساو اة و المشاركة.

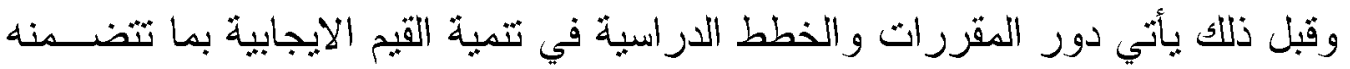

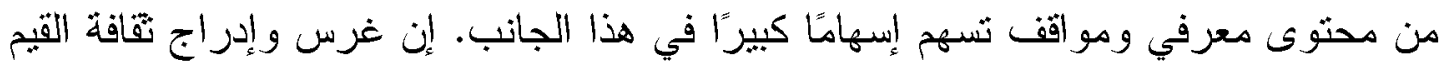

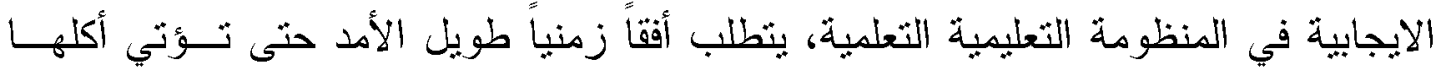

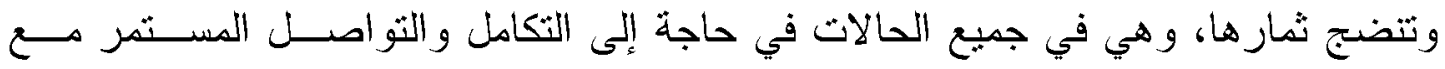

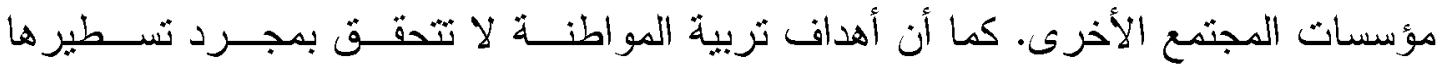

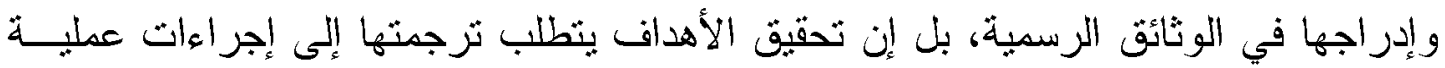

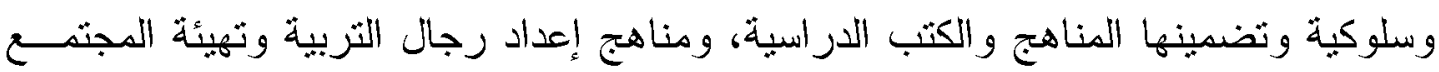

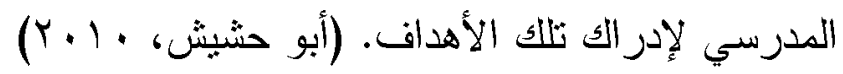

\section{المبالث الثالث}

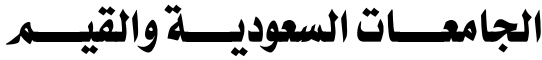

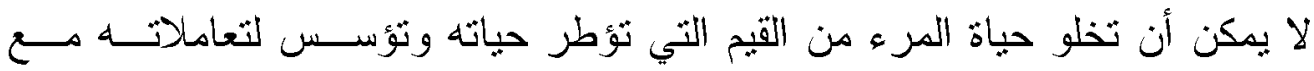

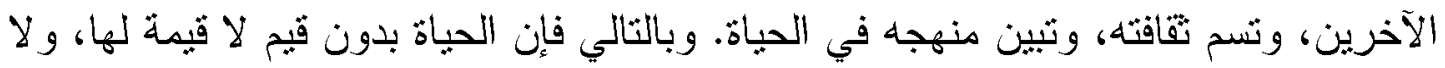

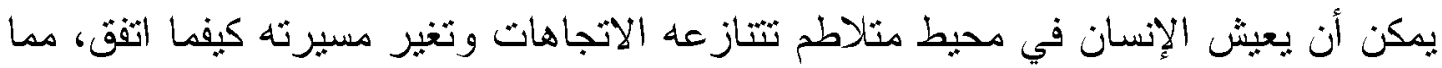
قد يقوده إلى عكس الاتجاه الذي بسعى إليه. وبنفس المفهوم فإن المنظمات الني تحثرم نفسها

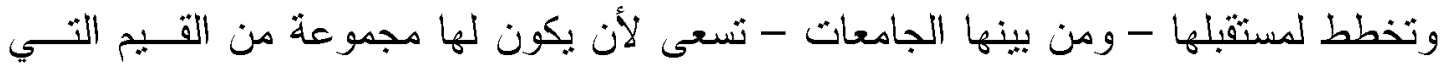

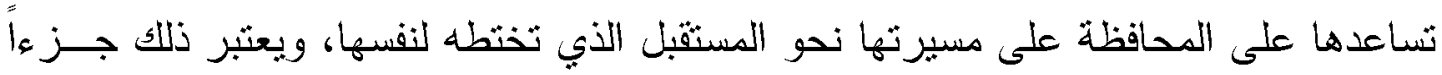


من نقافتها التظظيمية التي بعمل في ظلها جميع منسوبيها. حيث تثوم الجامعات بدور مهم تجاه

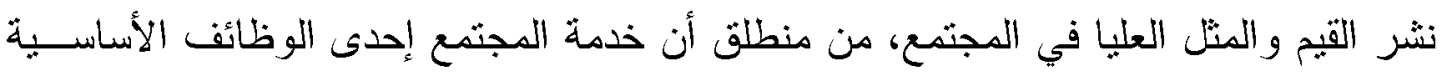

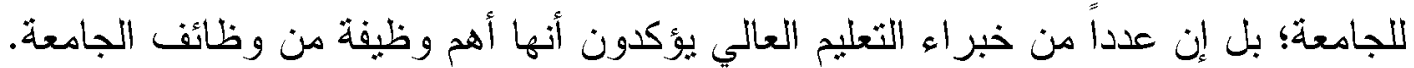

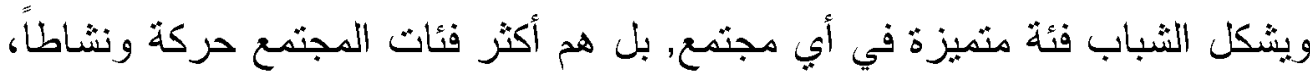

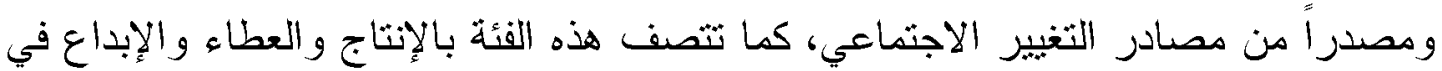

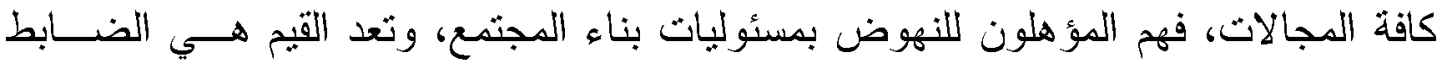

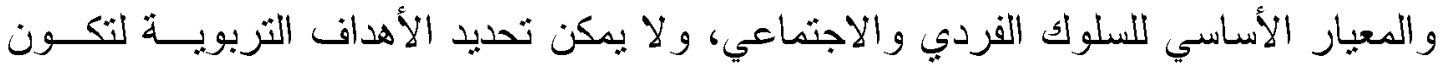

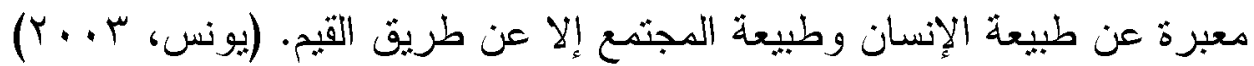

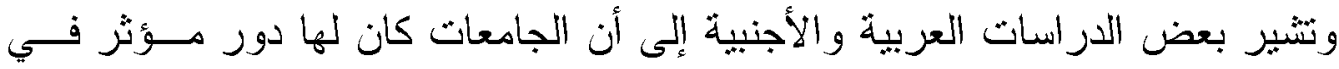

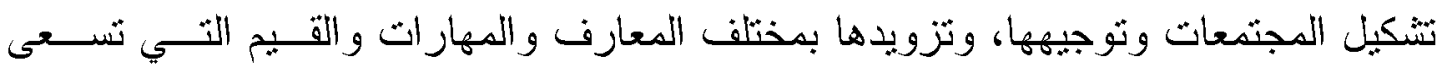
المجنمعات لترسيخها في نفوس أبنائها.

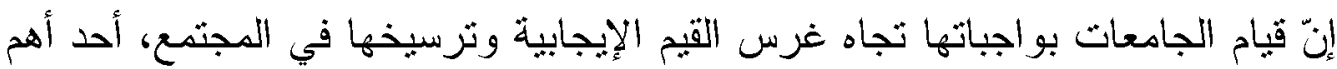

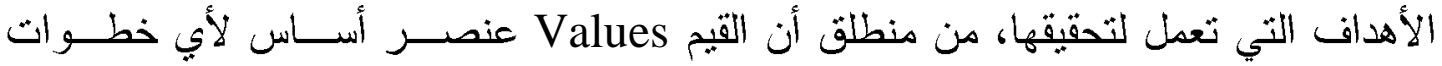

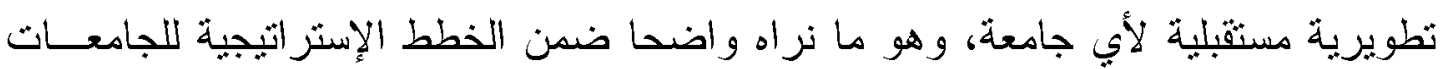

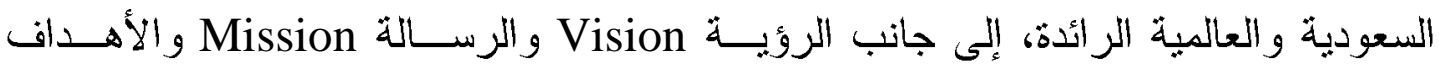

$$
\text { Goals }
$$

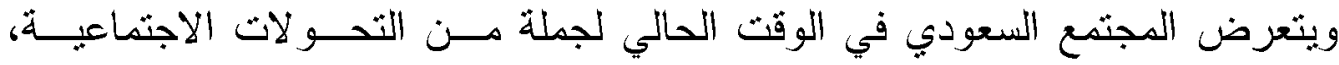

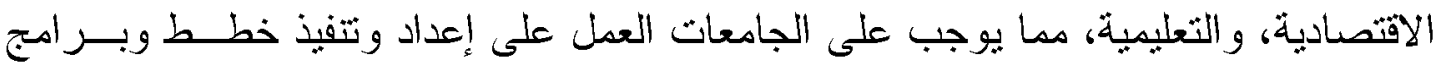

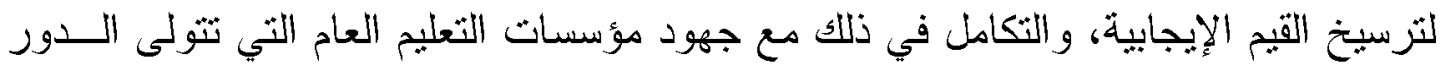

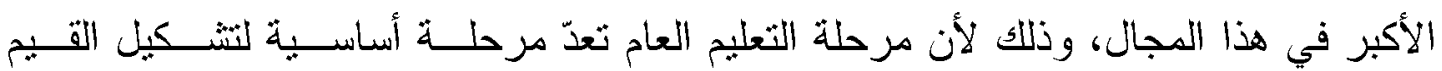

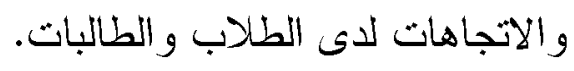

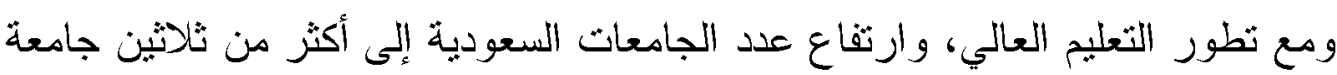

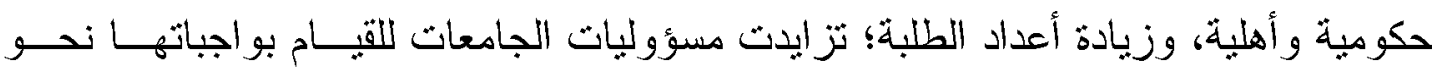

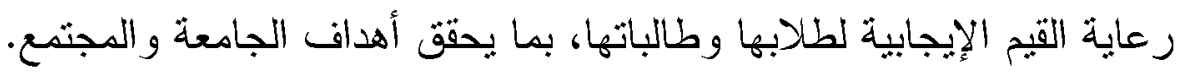

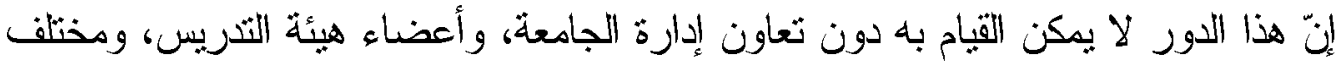

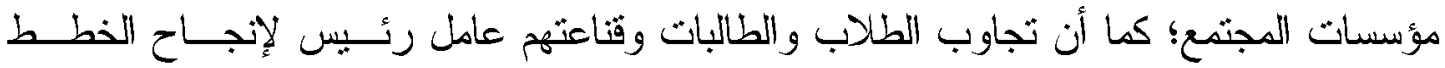

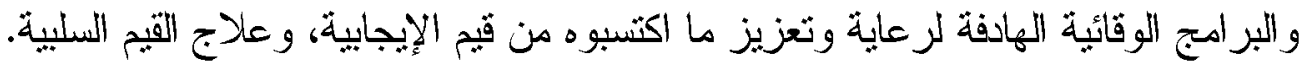




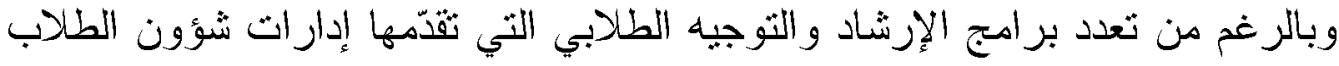

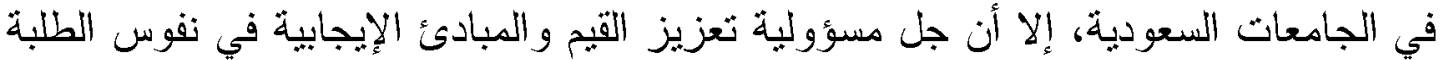

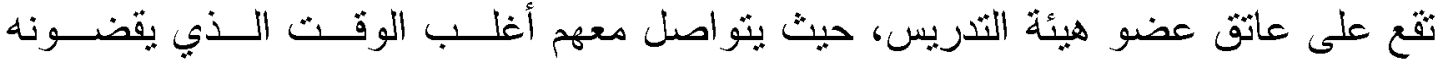

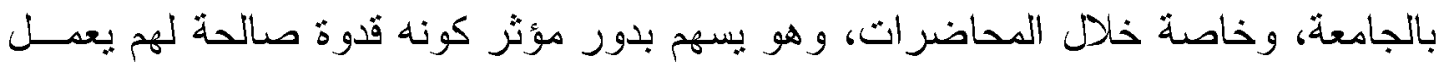

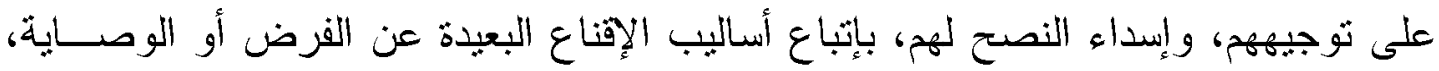

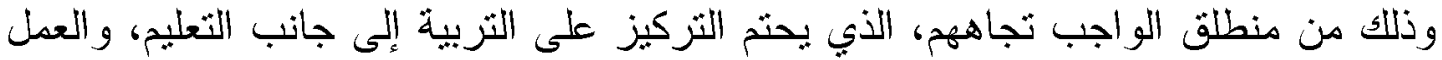

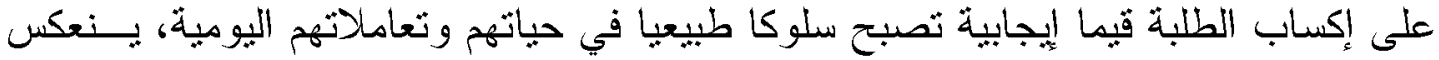

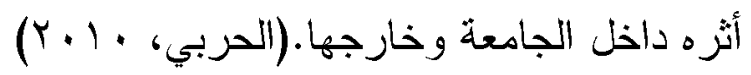

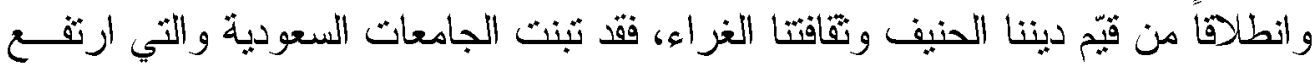

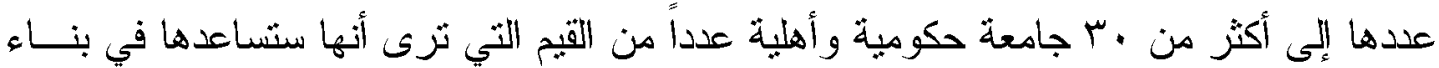

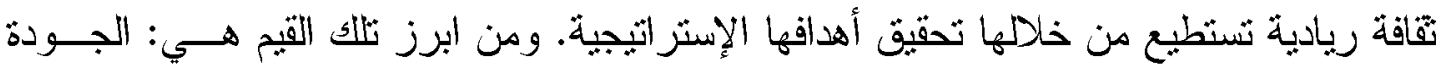

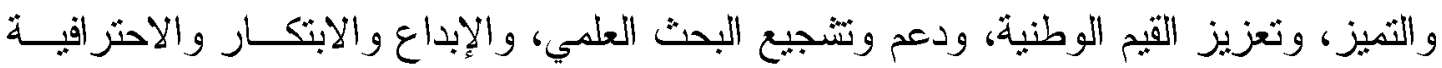

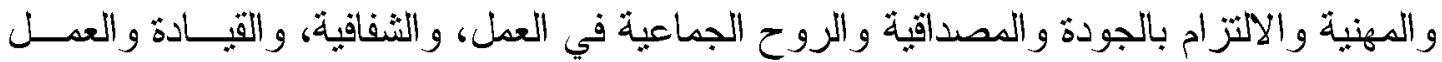

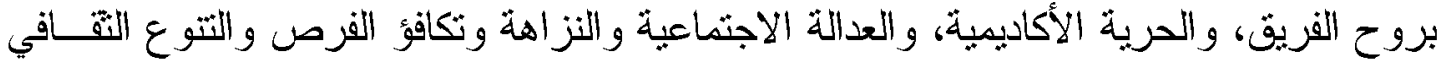

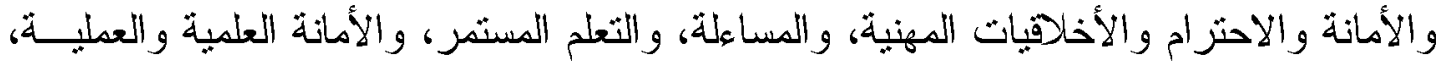
الإخلاص في العمل وإتقانه من قبل رئيس ومرؤوس، والو لاء للجامعة، و الاحترام المتبادل بــين الهيئة الندريسية والعاملين و الطلبة، وغبرها الكثير الكثير من القيم التي أخذت على نفسها العهـد بالمحافظة عليها وتعزيزها عند الطلبة و العاملين في الجامعات.

\section{المبحث الرايع}

\section{جهود الجامعات السعودية في المحافظة على القيم وتعزيزها لدى الشباب الشياه}

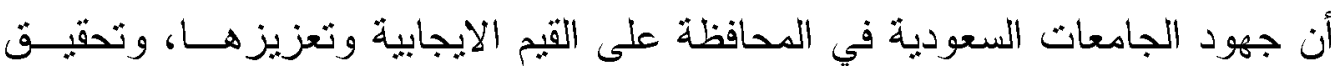

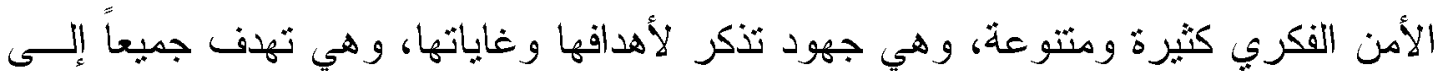

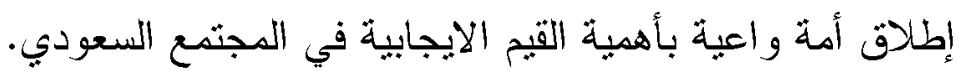

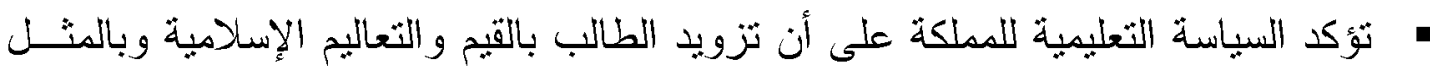

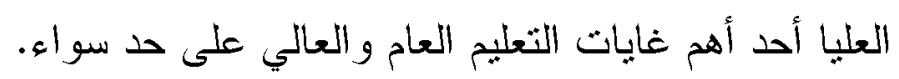

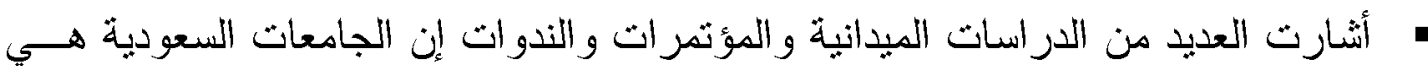
قلاعا حصينة لنشر فكر الوسطية والاعتدال وتحصبين عقول الثباب ولها الدور الكيبـر

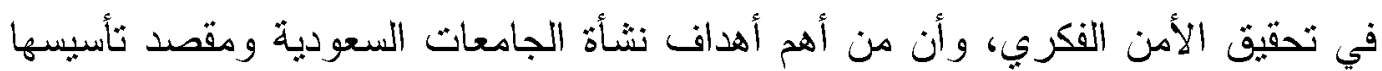




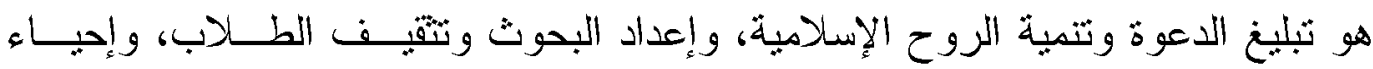

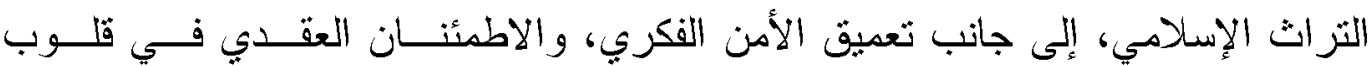
منسوبيها من الطلاب السعوديين و الو افدين. ولم تأل الجامعات السعودية جهاً في سبيل نحقيق هذا الهدف جهدا من خلادل المنــاهج

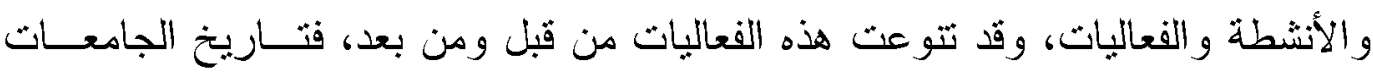
السعودية في الماضي و الحاضر شـاهد على ذلك.

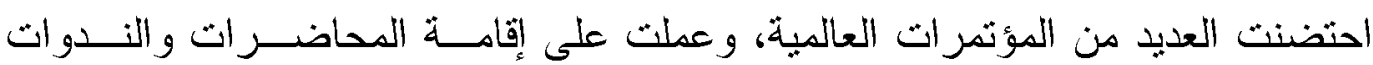

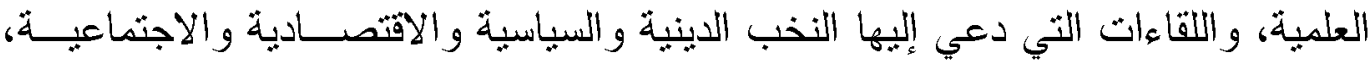

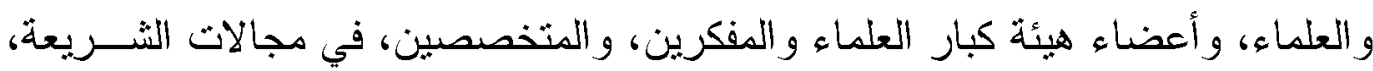

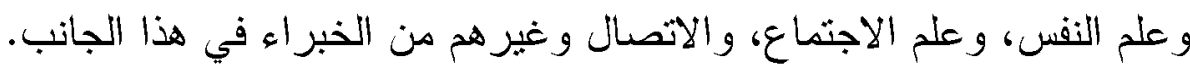

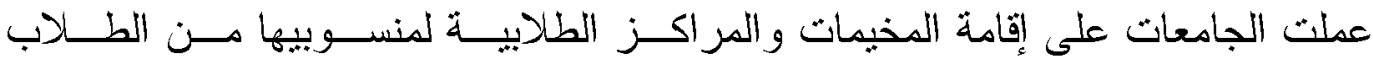

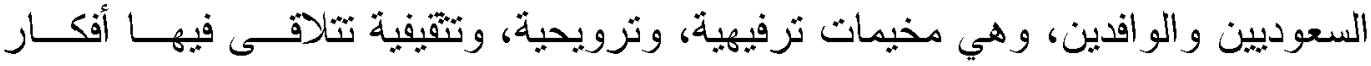

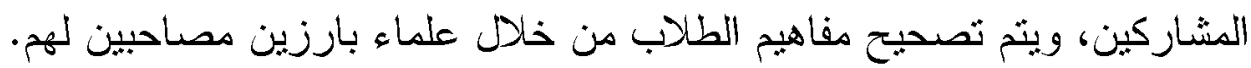

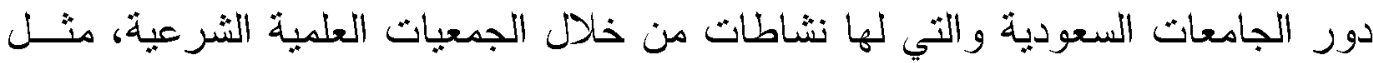

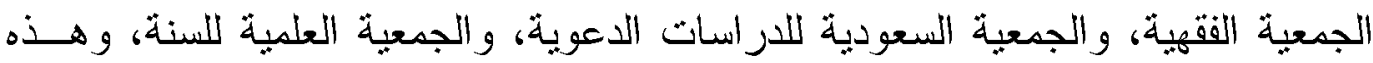

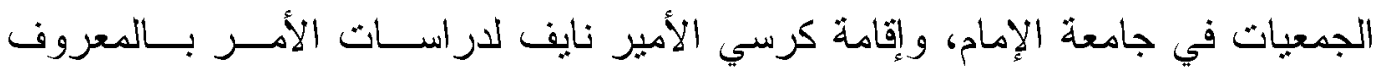

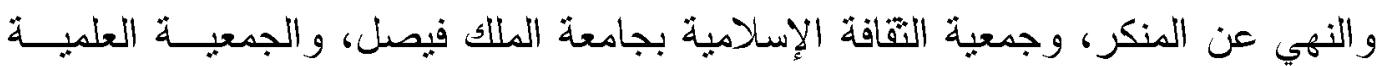
السعودية للار اسات الفكرية بجامعة القصيم. القية. فيما بتعلق بمحور الكراسي العلمية، فالكر اسي العلمية لا يخفى عليكم جميعا أن الجامعات

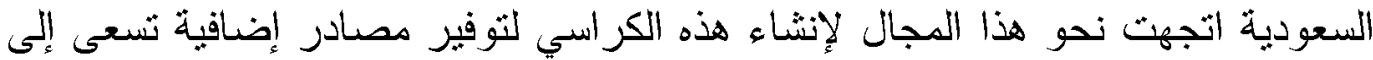

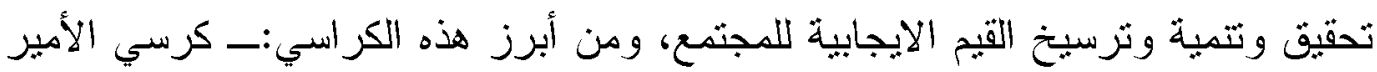

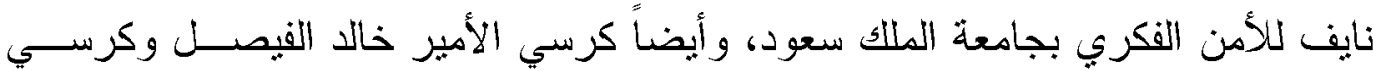

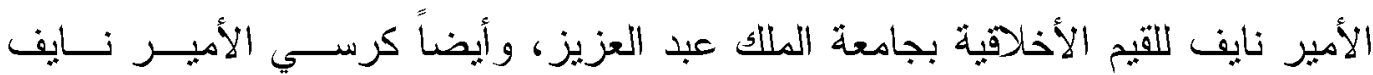

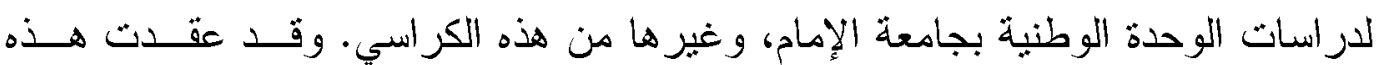

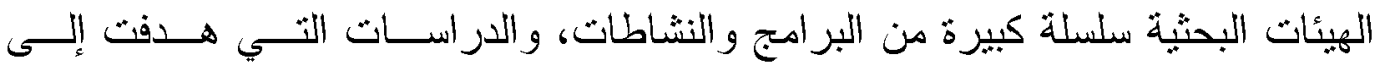

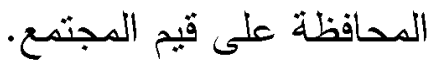


ومن أبرز جهود الجامعات السعودية في المحافظة على القيم وتعزيزها ما تقوم به كلبـــــا

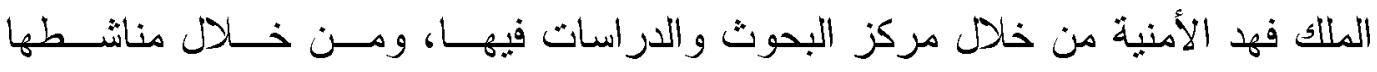

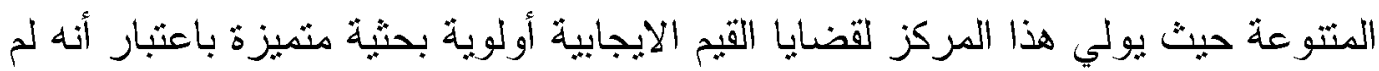
يعد فقط مجرد قضية أمنبة وإنما أصبح رأس القضايا العلمية.

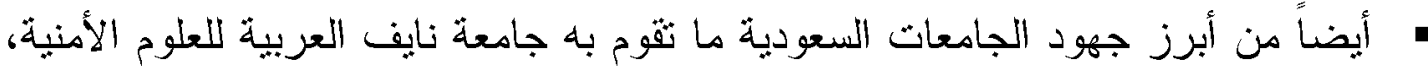

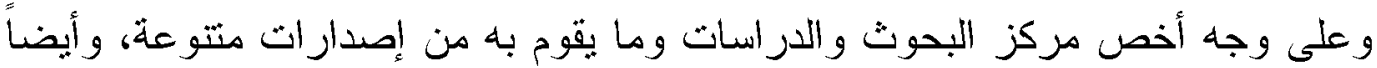

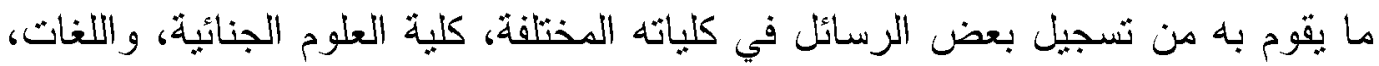

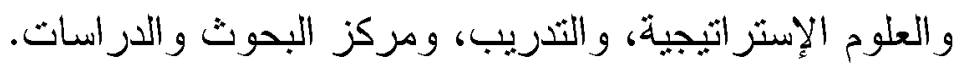

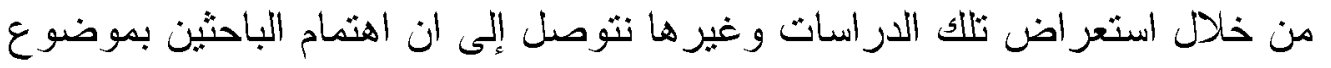

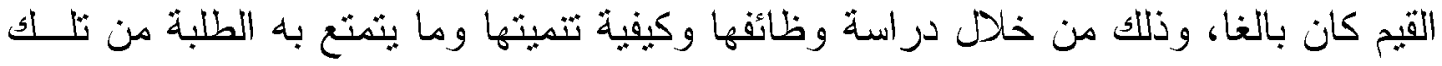

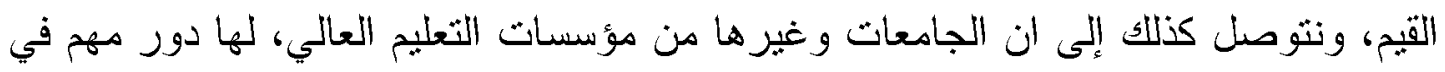

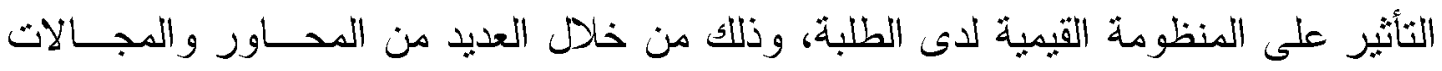

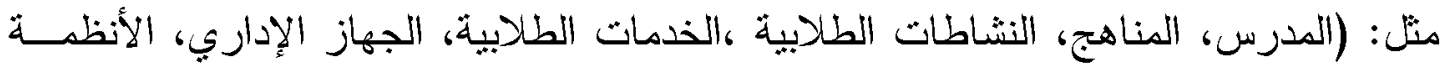

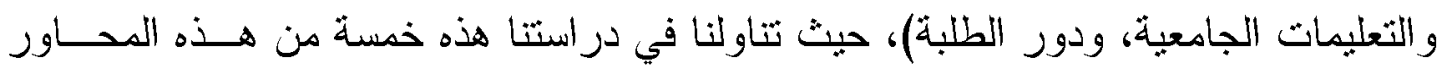

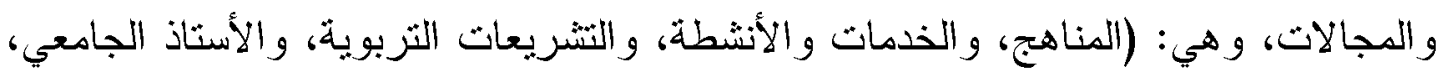
وأهداف الجامعة وسياساتها وفلسفتها) و ولنات

\section{الفصــل الثل الثان \\ دور مؤسسات التعليم العالي في المدافظة على القيم الايجابية وتعزيزهـا البحث بלول}

\section{دور أهداف الجامعة وسياستها وفلسفتها في المحافظة على القيه الايجابية وتعزيزها}

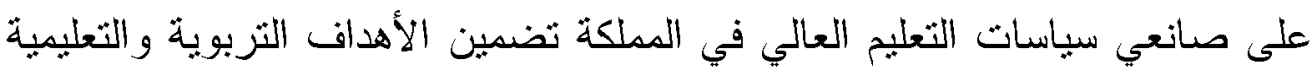

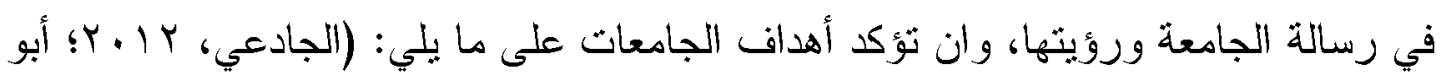

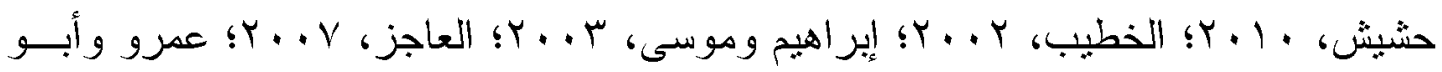

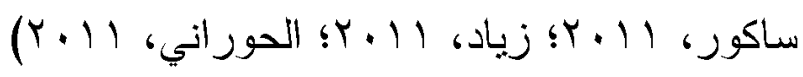

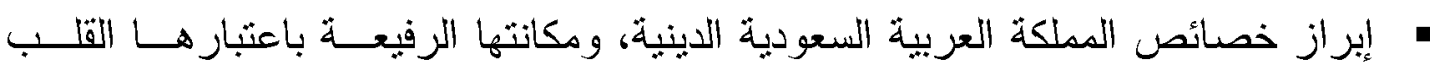

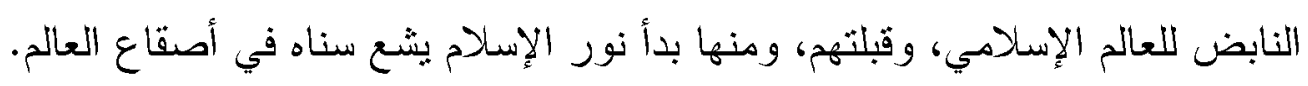




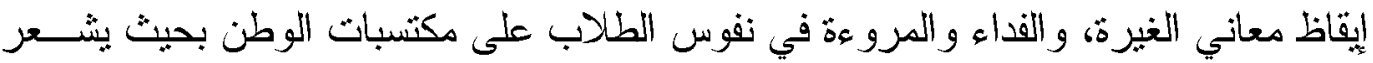

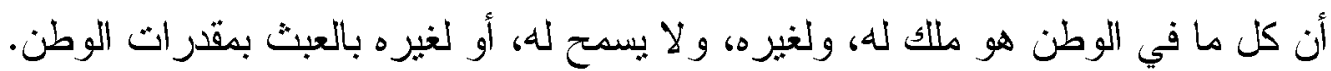

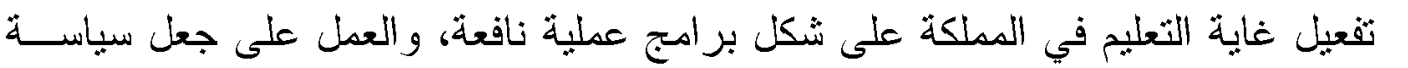

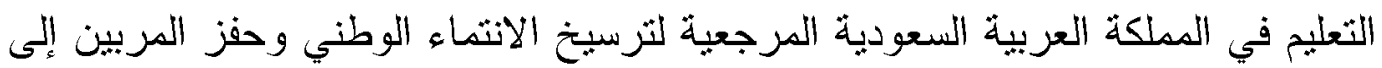
تعمبقه، وذلك لسلامة اتجاهاتها، ومنطلقاتها.

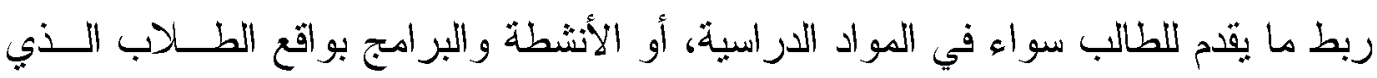

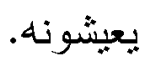
هدير الطلاب من الأفكار الهدامة التي يبثها مروجوها عبر القتوات المختلفة والثي نثؤدي

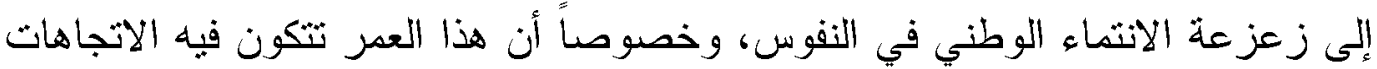
و القيم ويمكن ذلك عن طريق.

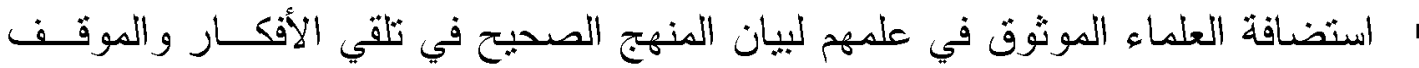
الصحيح منها. إقامة برنامج حواري دع الطالب للوصول إلى الثنبهات التي تساور عقله، و السعي إلى إبطالها.

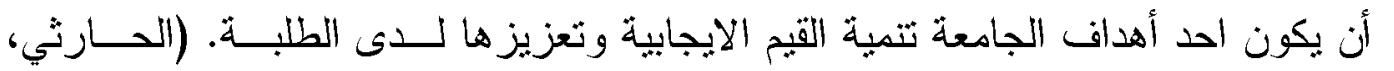

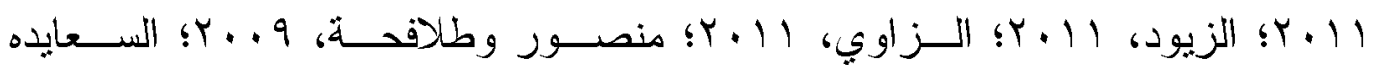

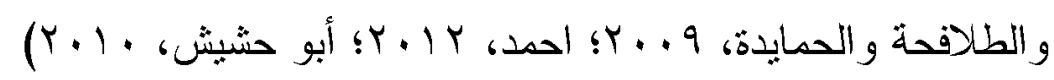
المابكث الثاني

دور التشريعات التربوية في المحافظة على القيه الايجابية وتعزيزها

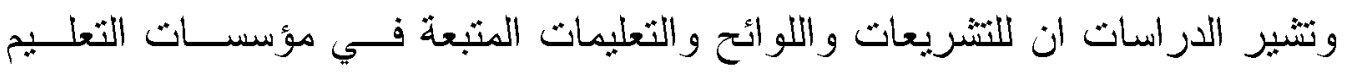

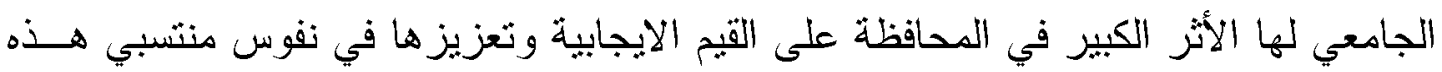

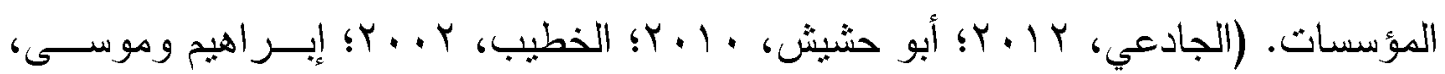

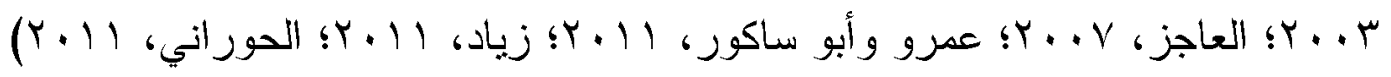
وضع تثريعات تحرص على تعيين القيادات و المدرسين من المعروفين بالثز امهم بـالقيم العربية و الإسلامية. وضع نظام للحو افز و الجوائز التقديرية للطلبة الذين بلتزمون بالقيم. وضع قانون لمعاقبة الطلبة والعاملين غير الملتزمين بالقيم.

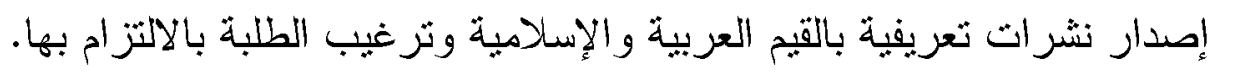
التزام العاملين في الجهاز الإداري بالقيم الإيجابية والمحافظة عليها. 
تسهيل الإجر اءات الإدارية وانجاز ها للطلبة بسرعة ويسر. • عمل دورات متخصصة للمدرسين والإداريين نتعلق بالقيم وكيفية تتميتها. • عل مسابقات دورية منعلقة بالقبر. التو اصل مع أولياء الأمور و الحديث معهم حول بالفمانغ القبم.

\section{الثبالث الثالث}

\section{دور المناهج في المحافظة على القيه الايجابية وتعزيزها}

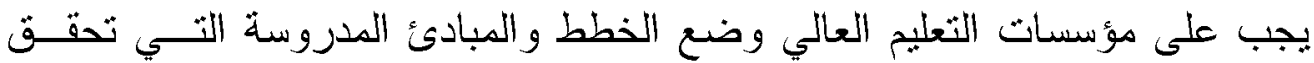

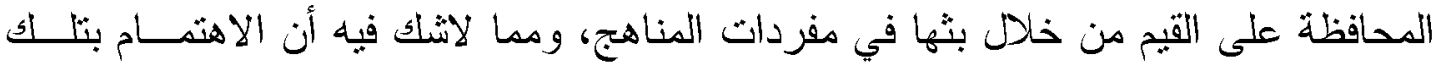

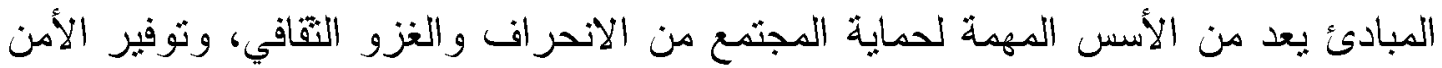

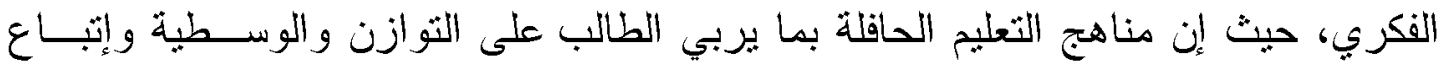

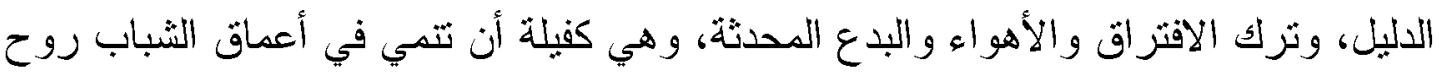

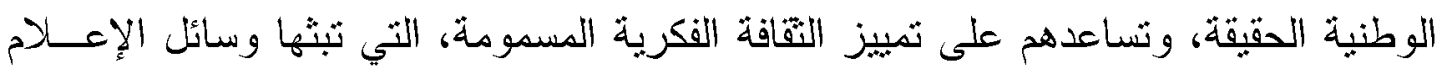

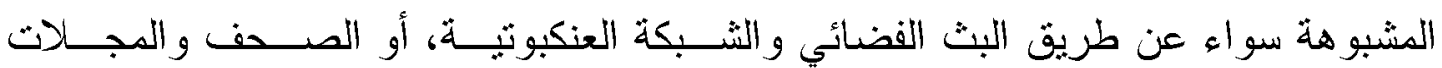

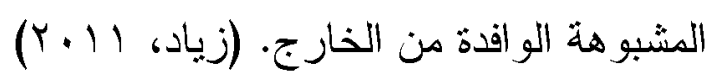

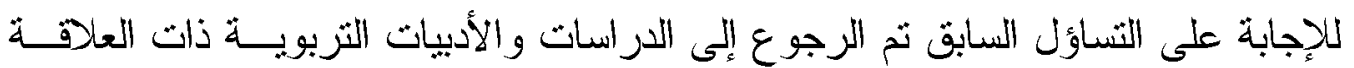

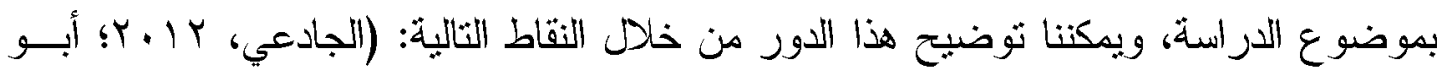

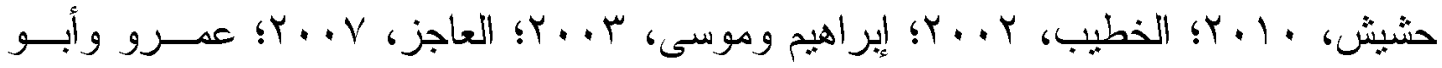

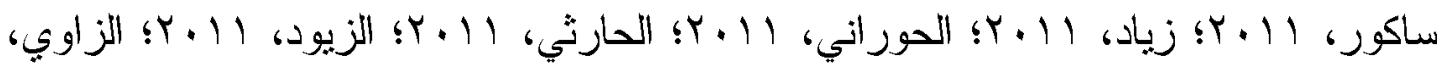

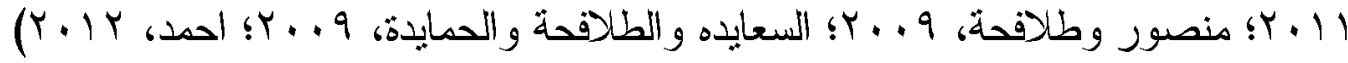

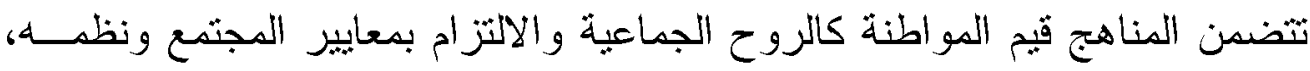

$$
\text { و الثُعور بالاتنماء ومفاهيم المساو اة، وضو ابط الحرية. }
$$

هتثم بإكساب التلاميذ الهوية الوطنبة والازتباط بالوطن.

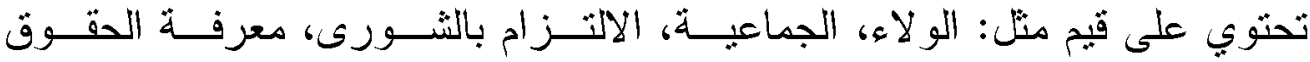

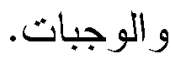

ينوفز مساق خاص بالمحافظة على القيم وتعزيزها. تتمي قدرة الطالب على التمسك بحقوقه. تساهم في تتمية القدرات الإبداعية. 


$$
\begin{aligned}
& \text { • تعزز قيمة حرية التفكير الجدي بمنكلات المجتمع. } \\
& \text { " تدعم روح التضامن بين الطلبة. } \\
& \text { " تتمي مبدأ حرية التعبير عن الرأي وثقافة الحوار الإيجابي. } \\
& \text { تثرز دور مؤسسات المجتمع في التنمية الاجثماعية. } \\
& \text { ربط مفردات المساقات بالقيم المتعلقة بها. } \\
& \text { • طرح مساقات منخصصة منعلقة بالقيم لجميع طلاب الجامعة. } \\
& \text { - اشتمال مساقات متطلبات الجامعة على فصول خاصة بالقبه. } \\
& \text { • ان نكون منطلبات بعض المساقات نشاطات منعلقة بالقبم. } \\
& \text { " تضمين خطط المساقات مراجع تهنم بالقيم. }
\end{aligned}
$$




\section{إنبثث الرايع \\ دور الأستاذ الجامعي في المحافظة على القيه الايجابية وتعزيزها؟}

أما نور الأستاذ الجامعي فهو عظيم ومهم، وتحمل الجزء الأكبر في تعزيز القيم الإيجايية،

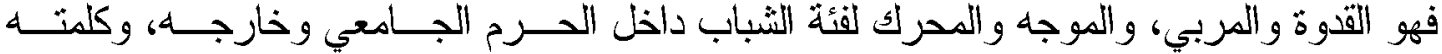

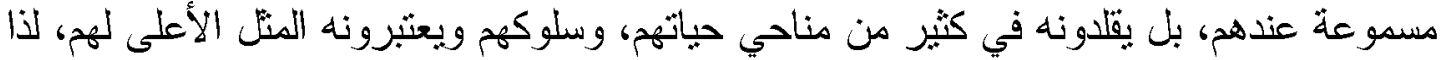

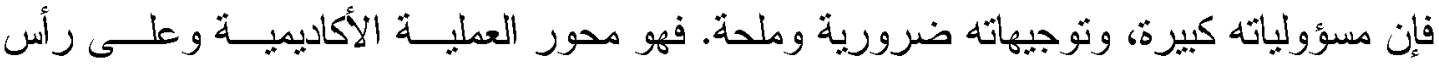

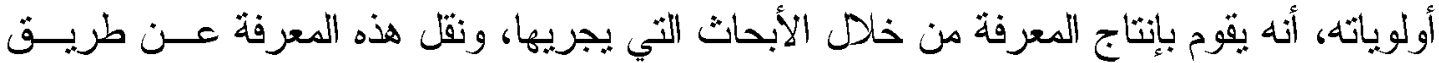
التدريس للطلبة الذين هم أمانة في عنقه، وهو حجر الزاوية في العمل الأكاديمي الذي يرتكز أساسا

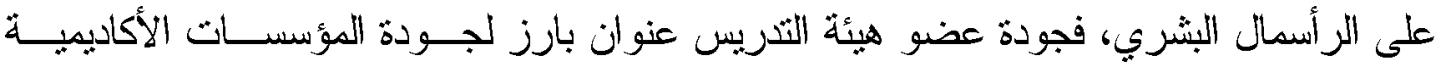

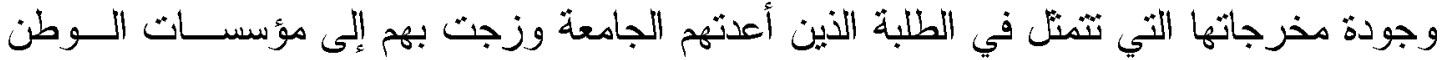

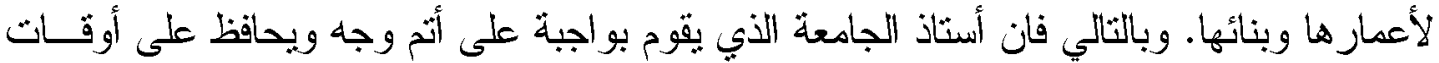

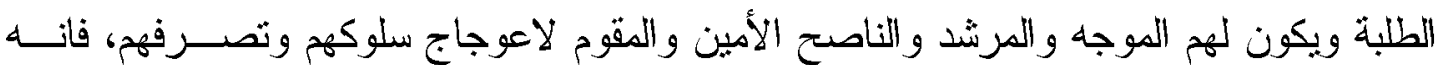

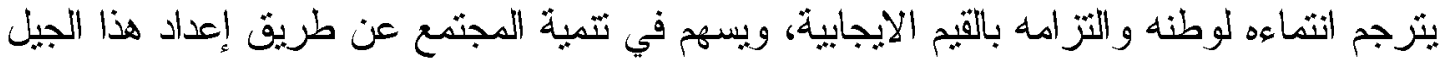

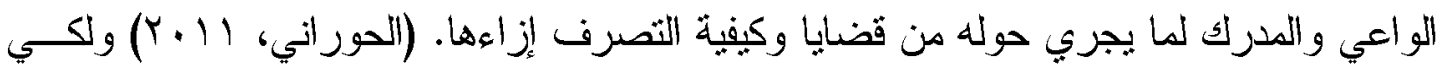

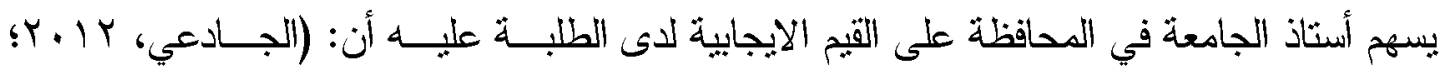

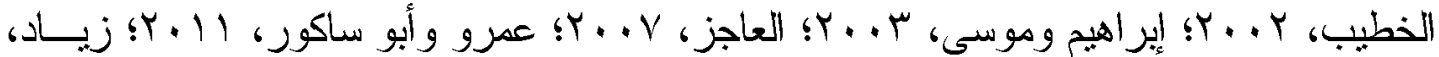

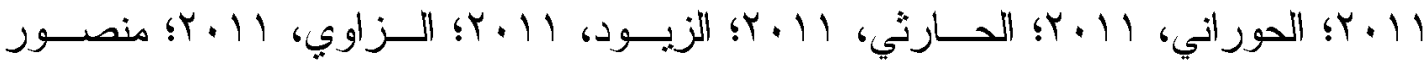

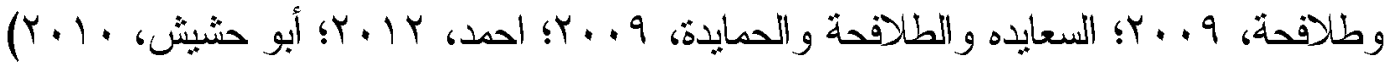

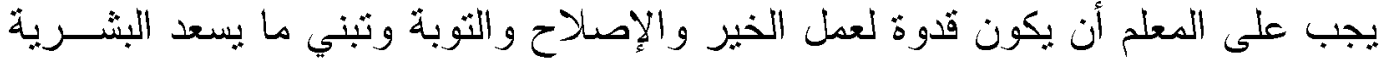

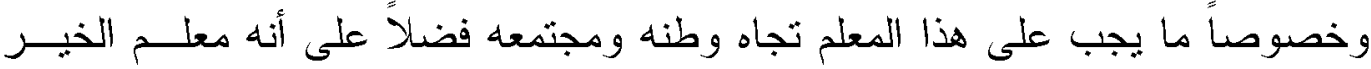
ويحمل مسؤولية جسيمة.

ولكي يقوم المعلمون بدورهم في التوعية والوقاية من الانحر اف، فلابدّ لهـم أن يقوهــوا بتنشئة الطلبة تنشئة إسلامية صحيحة.

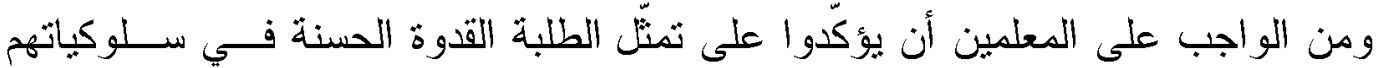
وتصرفاتهم، وفي الانسجام مع قيم المجتمع وقو انينه. 
ترسيخ مبدأ الحوار الهادف والاستماع للآخرين واحثر ام آرائهم بقصد الوصول إلى الحق

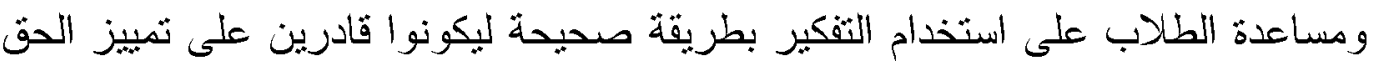
من الباطل و النافع من الضار وتنمية الإحساس بالمسؤولية لدى الطلاب.

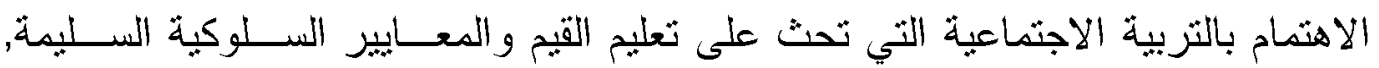

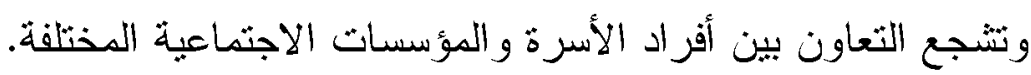
توجيه الثباب لطرق البحث عن المعلومات الصحبحة وتشجيعهم على ذلك، وتفهر طبيعة

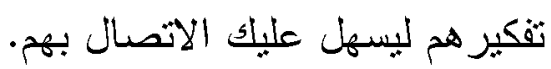
" مساعدة الطلاب على استبعاب المفاهيج والأفكار التي نتعلق بالحباة و المستثبل، والبعيــدة

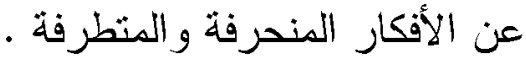
يحرص على ثرجمة خبراته الإيجابية إلى ممارسات فعلية، وان ينطابق سلوكه مع أفكاره في المو اقف النعليمية التعلمية. يتزجم القيم الايجايية إلى سلوكيات محمودة، ويبتعد عن الطرق الثقليدية في التدربس الني تعتمد على التلقين. يستخدم طرق تدريس مناسبة: كالعصف الذهني ودراسة الحالة والمناقتشة والمجموعات. بحترم استثالية الطالب وتثكيره، وينتعامل معه بقدر من المرونة و التشامح و التعامل بعقانية.

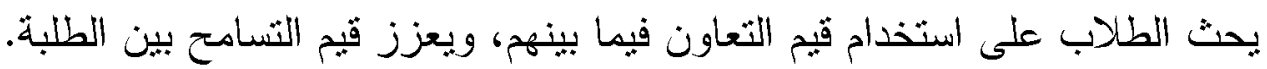

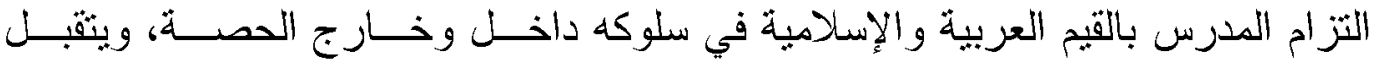
بمحاورتهم باحترام داخل وخارج الحصة.

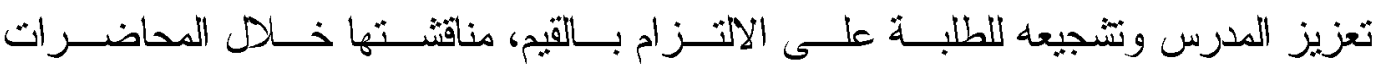
وربطها بحياتهم. • استعداد المدرس لإبداء النصح لمن يطلب من الطلبة ومساعدنهم في حل مثكلاتهم. الكفاءة العلمبة للمدرس، وتتويعه في طر ائق التدربس التي بستخدمها.

\section{المابكث الغامسل}

\section{دور الخدمات والأنشطة في المحافظة على القيم الايجابية وتعزيزها؟}

للإجابة على التساؤل السابق نم الرجوع إلى الدراسات و الأديبات التربوية ذات العلاقة

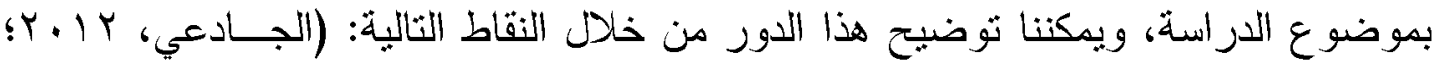

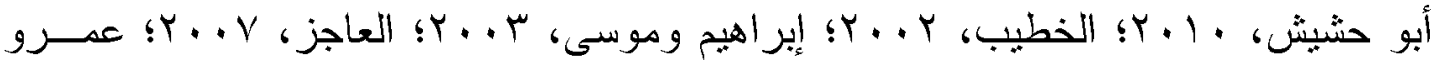

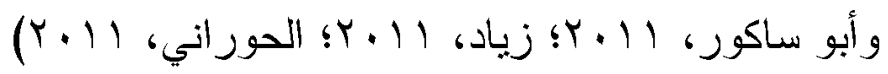




\section{تعزز القيم الإيجابية وتحافظ عليها. \\ ترنبط بنبض المجتمع وقضاياه و همومه.}

تثمل ندوات ثقافية بنت خلالها دعوة المسئولين في القضابا المختلفة.

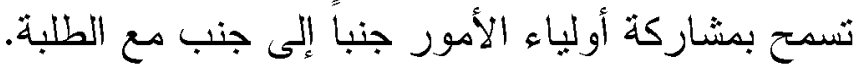

هز اعي فرص المشاركة للطلبة بدون تمييز.

تتيح الفزص لمؤسسات المجتمع للمشاركة فيها.

تعزز قيمة نبذ العنف و الثمييز بكل أثنكاله.

تنمي قيم التعاون بين الطلبة.

الالتز ام بالقيم في كافة النشاطات الطلابية.

استثمار الرحلات العلمبة والترفيهية لغرس القبم لاى الطلبة.

ه إقامة محاضرات وندوات وورش عمل للحديث عن القيم والالتزام بها.

التأكبد على القيم من خلال النشرات و اللوحات الجدارية.

تتكبل لجان طلايية لحض الطلاب على الالتزام بالقيم.

الجمعيات و النوادي الني ينشئها الطلبة داخل الجامعة.

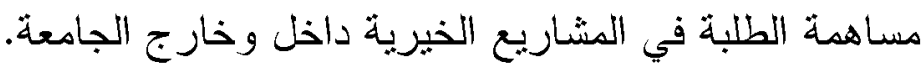

مشاركة الطلبة بحوارات وندوات مع المسؤولين حول قضايا الأمة الرئيسية.

مشاركة الطلبة بدراسات مبدانية لاستقصاء القيم السائدة.

انضمام الطلبة لجمعيات ومؤسسات خيرية وسياسية خارج الجامعة.

التزام القائمين على تقديم الخدمات بالقيم المطلوبة.

الحرص على تقديم الخدمة بأفضل صورة.

تشجيع الطلبة على الالتز ام بالقيم من قبل مركز الإرشاد النفسي.

توفير مادة مكتبية منتو عة ومشوقة منعلقة بالقيم والالتز ام بها.

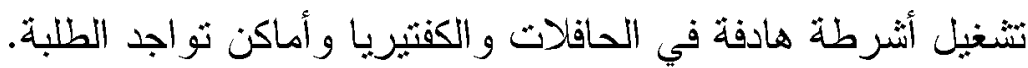

تواجد رجال الأمن بين الطلبة وحتُهم على الالتزام بالقيم.

\section{توصيـات الدراسيستة:}

تأتي أهية هذه الدراسة من موقع التعليم الجامعي في برامج التتمية و التطوير و الثقام في المجتمعات الحديثة من جهة، ومن موقع القيم الايجابية في البنية التقافية والحضارية لهذه لهنه 
المجتمعات من جهة أخرى، بوصف القيم رأس مال المجتمع، وأساس أبي إصلاح ثربوي فيه.

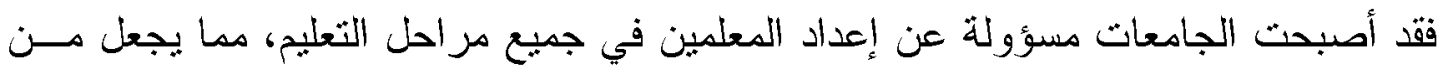

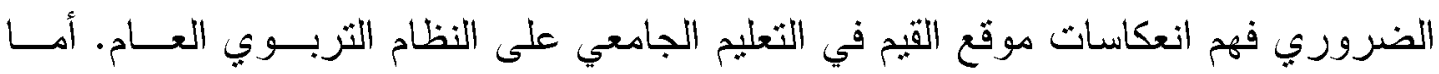

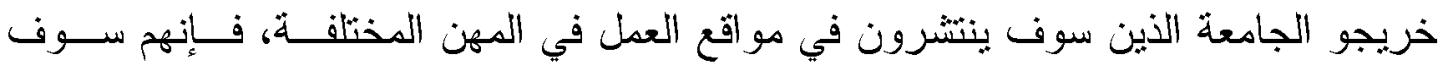

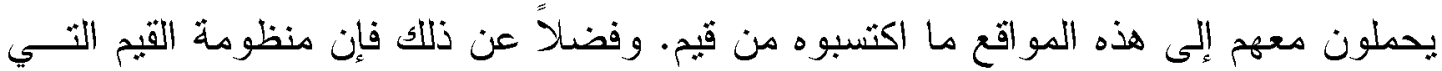

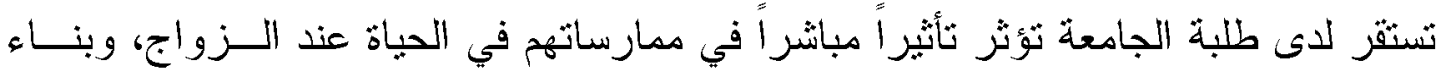

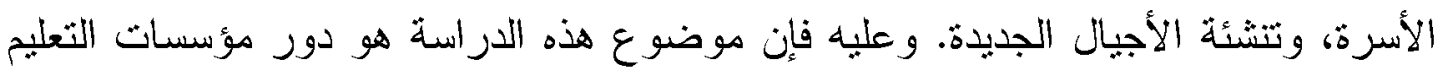

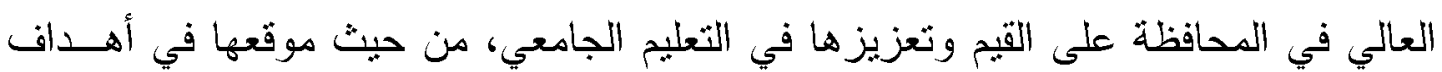

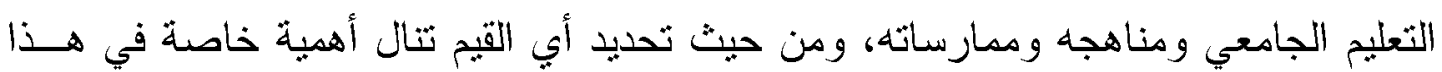

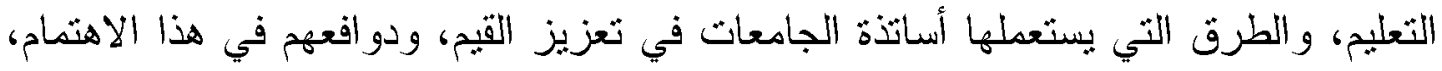

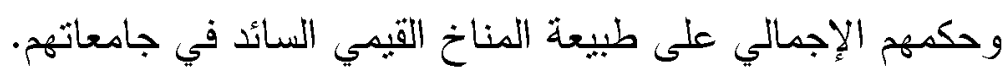

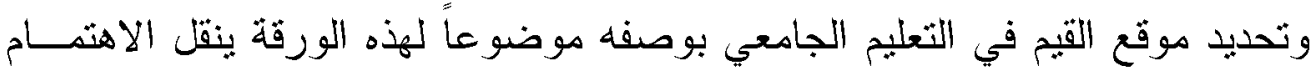

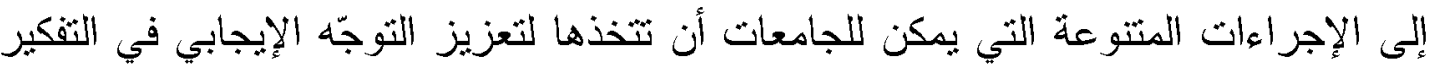

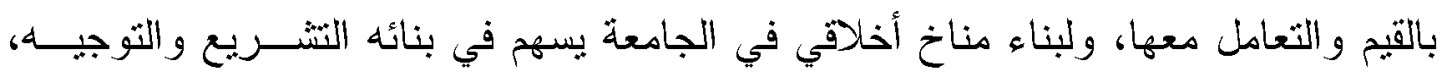

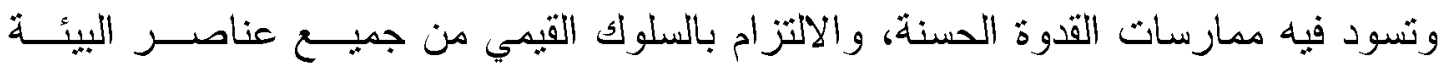

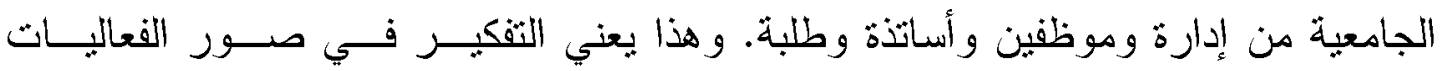

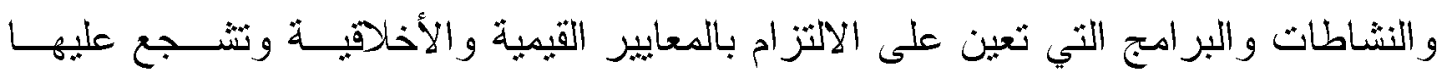

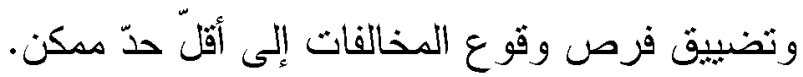
لقد أثنارت الدراسة إلى عدد من الأدوار الخاصة التي يمكن من خلالها لمؤسسـات

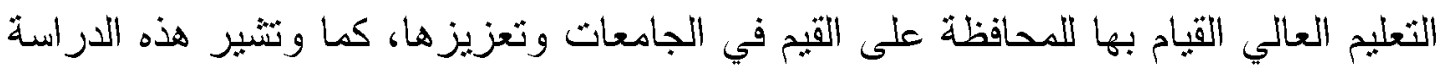

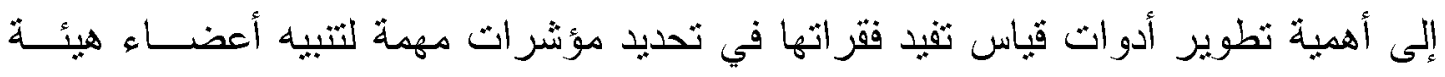

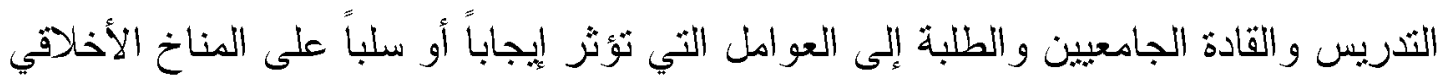

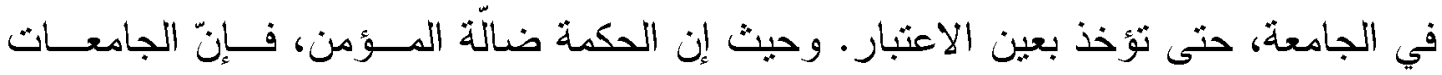

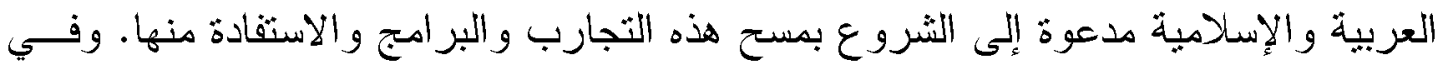

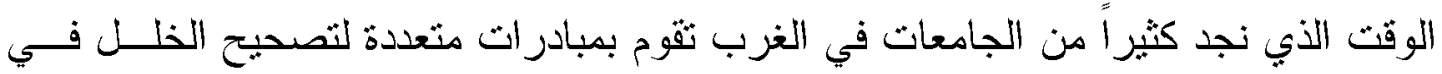

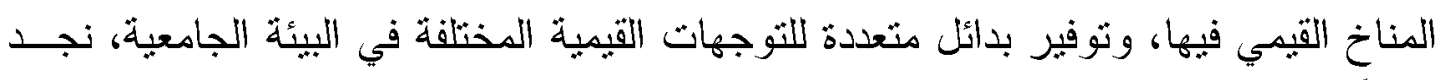

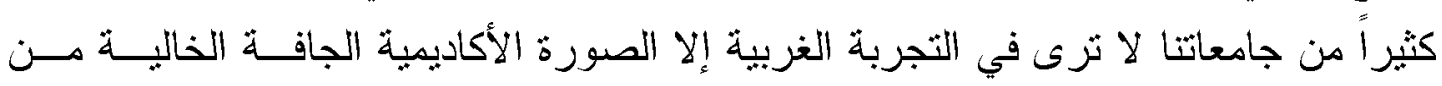

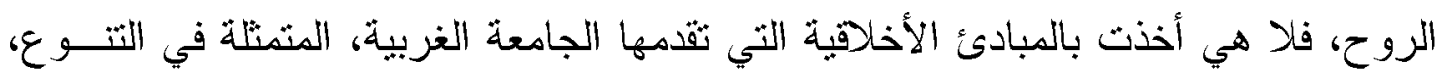


وإيجاد البدائل، وحرية الاختيار، واحترام الكر امة الإنسانية للمعلم والمعلم، و لا هي أبـدعت

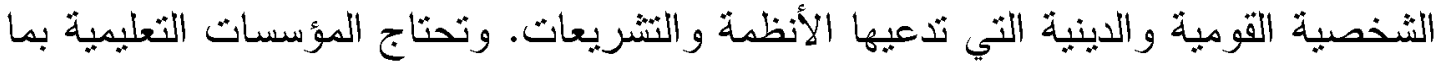
فيها الجامعات للقبام بدور ها الريادي في تتمبة القيم. وتثترح الدراسة مجموعة من التوصيات لتفعيل دور الجامعات السعودية لتتمبة القيم لدى طلبتها، ويمكن حصر ها فيما يلي:

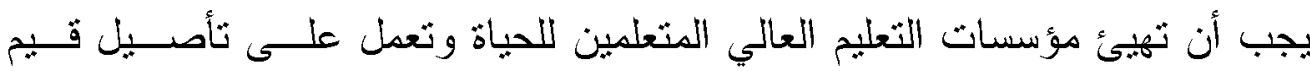
الانتماء و الو لاء للاين والوطن لديهز على اختلاف أعمار هم وقدراتهم، وهذا لا يتم إلا من خلال أساليب نعليمية منطورة تعمل على ترسيخ هذه المفاهيم.

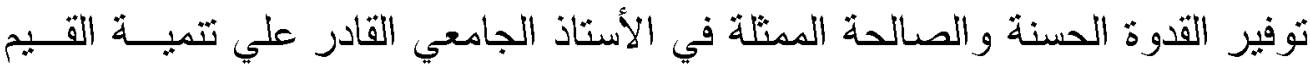
الدينية والأخلاقية، والذي يقع عليه الدور الأساسي في المحافظة على القيم الايجابية

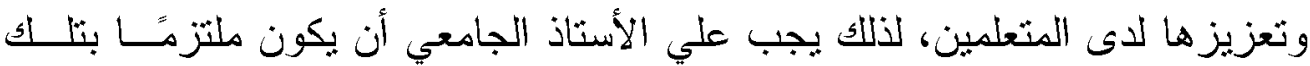

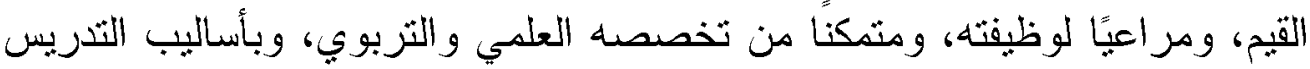

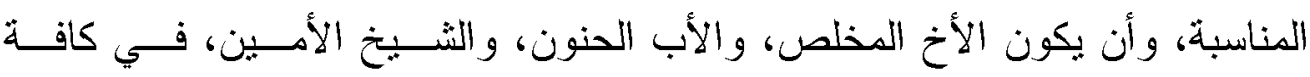
تصرفاته مع الطلبة، لأن المناهج منفردة لا تكفي للتعلم إذا كانت تهمل الجانب العابل العدلي

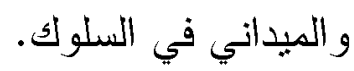
إنشر الك الطلبة في الأنشطة والخدمات الاجنماعية التي تشهم في حل القضــايا التـي تو اجه المواطن، تسهم في غرس قيم الروح الوطنية لدى الطلبة، وكذللك لا بد إبراز

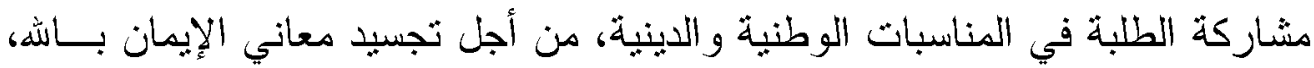

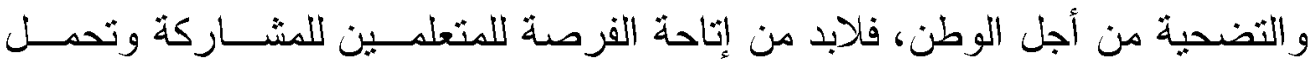
المسئولية إزاء القيم المطلوبة، و هذا بحتاج إلي الاهنمام بالأنثطة التحليمبة المتنوعة.

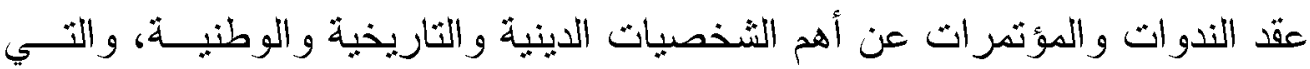

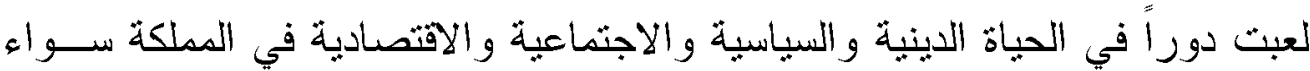
أكانت هذه الثخصيات أديية، أو علمية، أو اجنماعية، أو سباسية. إعادة النظر في المقررات الدراسبة في الجامعات، وخاصة مقررات التربية الوطنية

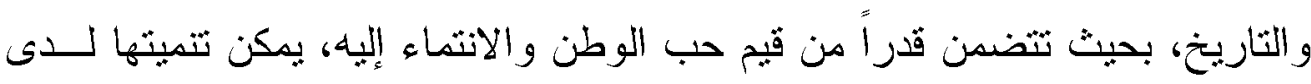

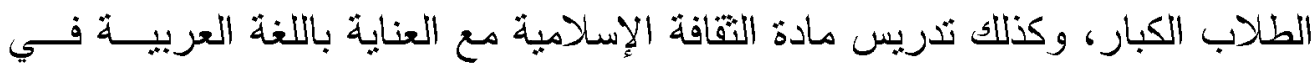
كليات العلوم الإنسانية و العلوم التطبيقية البحتة.

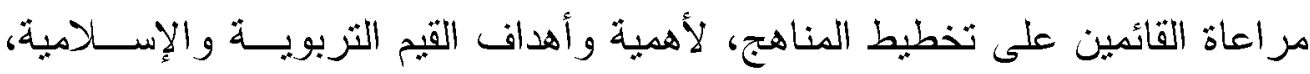

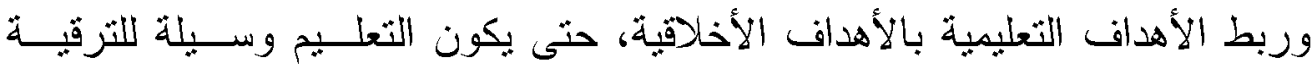


الأخلاقية الثي تغرس قيم المثل العلبا و الفضائل، و التمبيز بين الخير و الثُر، والحـق

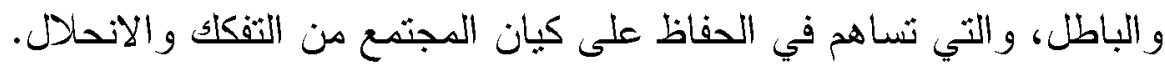

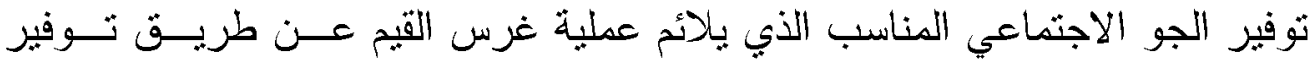

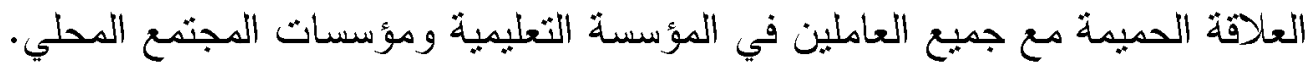

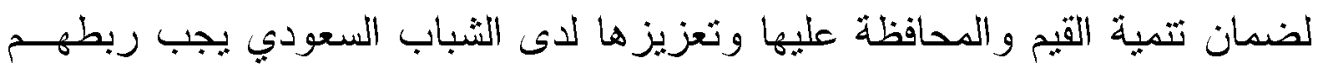

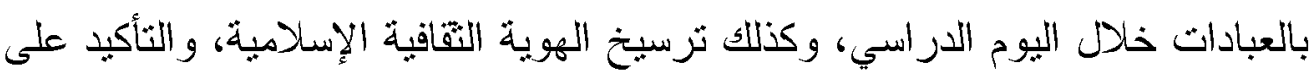

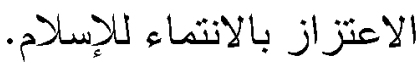

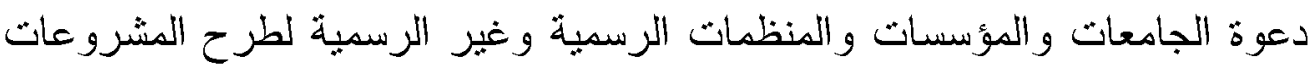

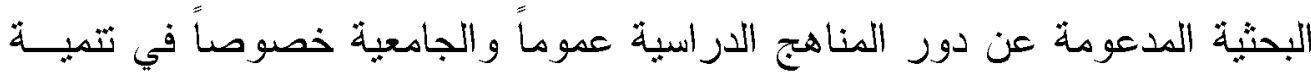
القيم و المحافظة عليها وتعزيز ها و انتقاء الباحثين المدربين لإجرائها.

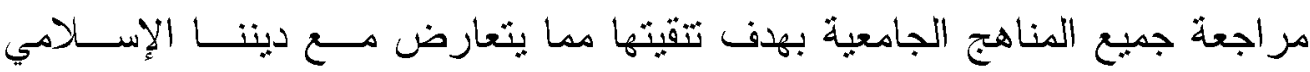

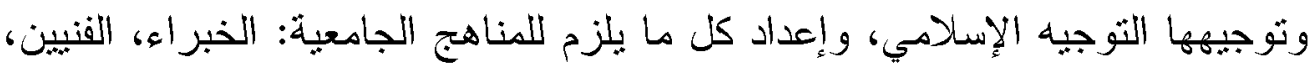

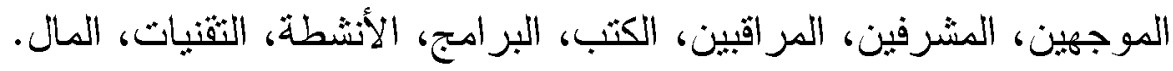

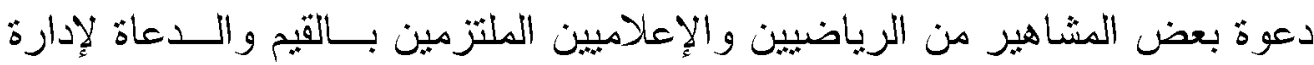

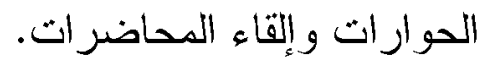

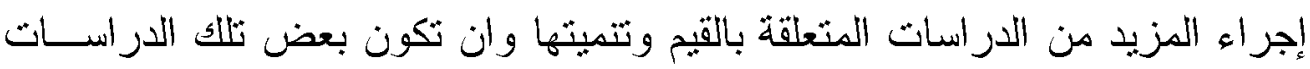

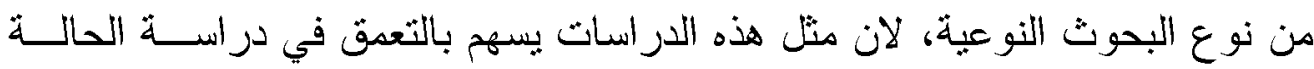
ومعرفة مكنوناتها وأسر ارها. إجر اء مر اجعة شاملة لكافة التشريعات و اللوائح الداخلية للجامعات، وتعزيز تلكاتك التي

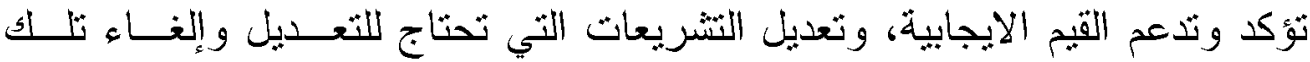

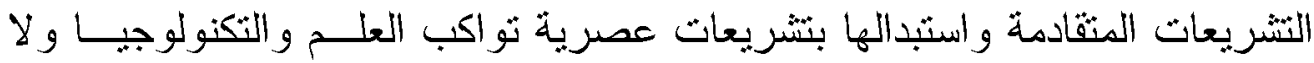
تخرج عن روح الإسلام وقيمه وأصالثه ومبادئه. 


\section{مراجـع الدراســة}

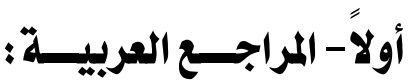

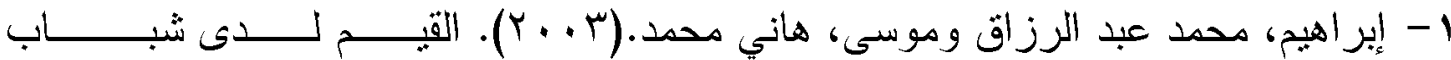

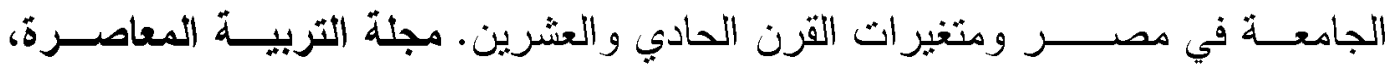

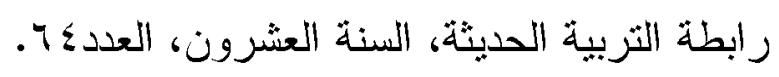
ץ-أبو العينين، علي خليل (911 (1)، القيم الإسلامية والتربية، طا مكثبة إبــر اهيم الجلبـيكي،

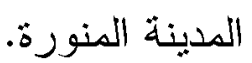

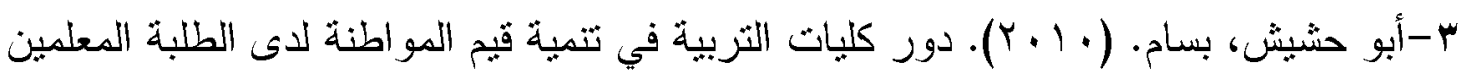

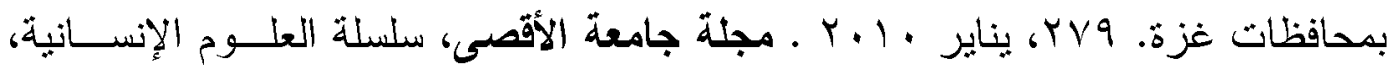

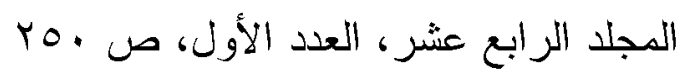

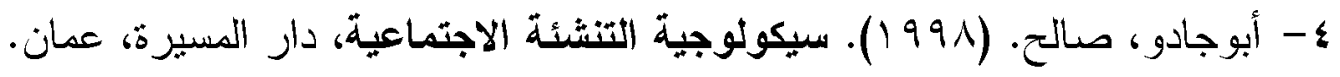

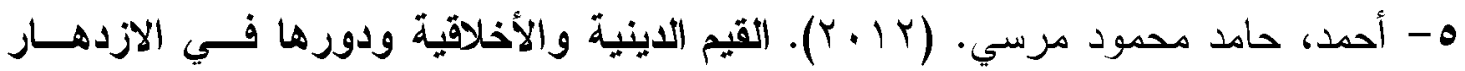
الاقتصادي. القاهرة : دار الطلائع للنشر و التوزيع.

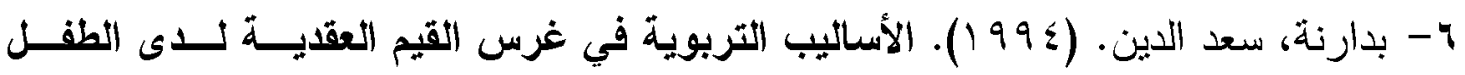

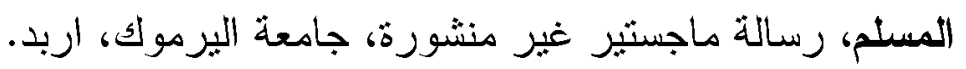

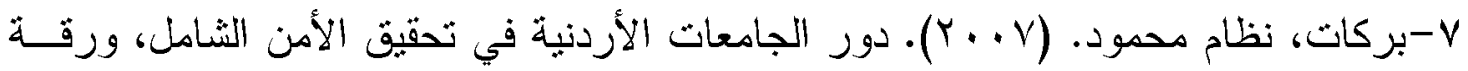

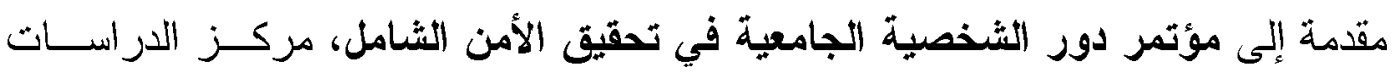
الإستر اتيجية الأمنية، عمان.

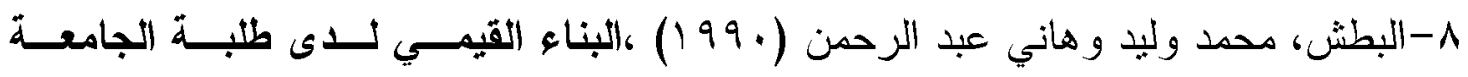

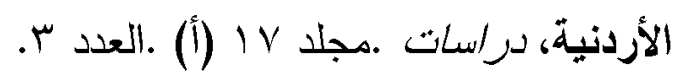

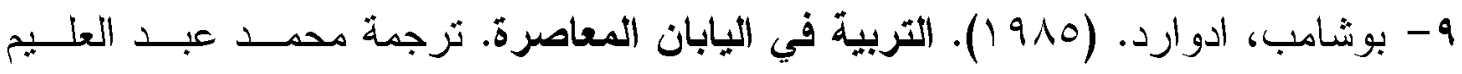

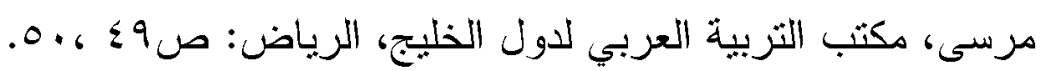




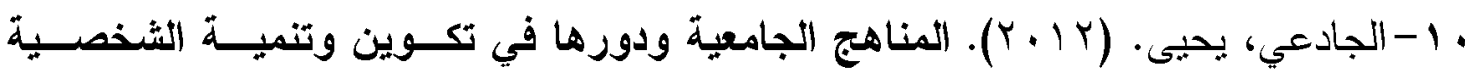

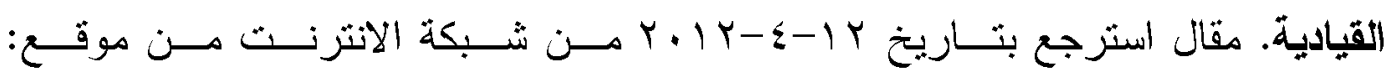
/http://www.alukah.net/Publications_Competitions/0/38157 11- الجلاد، ماجد (1999).النظام القيمي في ضوء توجيهات التربية الإسلامية ،مجلة العلوم

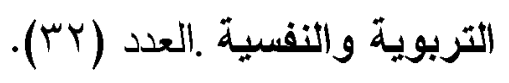
r ا - الحارثي رتركي بن عجلان و آخرون . (2011).الثباب وقيم المواطنة في المجتمـع السعودي ردار حافظ للنشر والتوزيع.

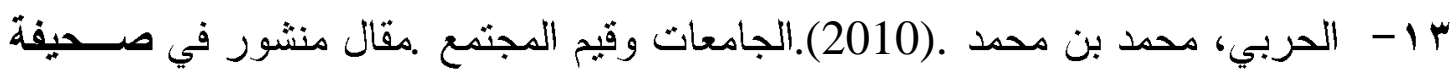

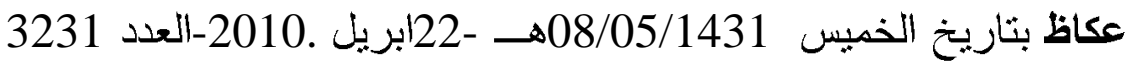
ـ ا- - الحوراني، احمد .(2011) .دور المؤسسات التعليمية في تعزيز الاتتــاء الــوطني . مركز الر أي للار اسات .عمان، الأردن.

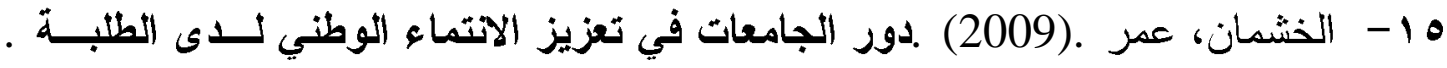

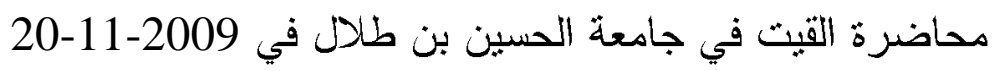
18 - الخطيب، خالد محمد .(2002) .دور الجامعات في تنمية القيم عند الطلبة، اســنلاع

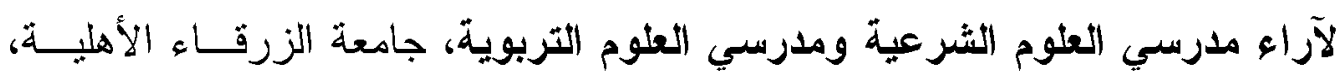

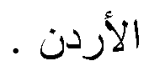

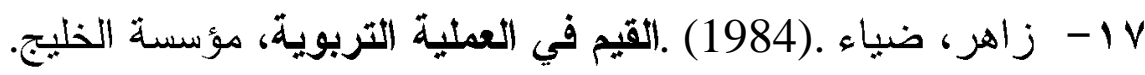

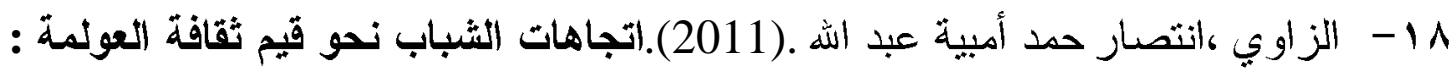

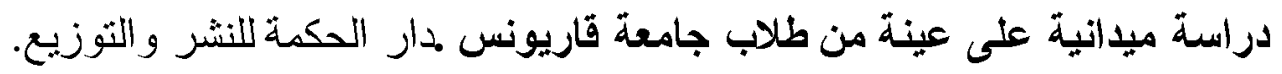

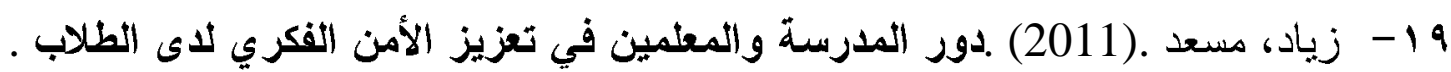

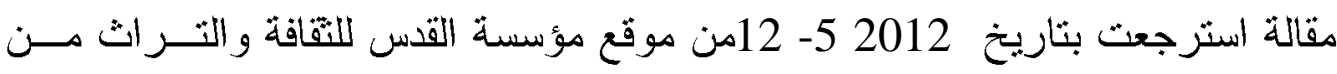

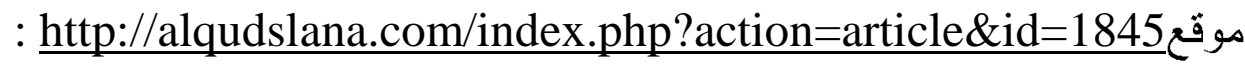

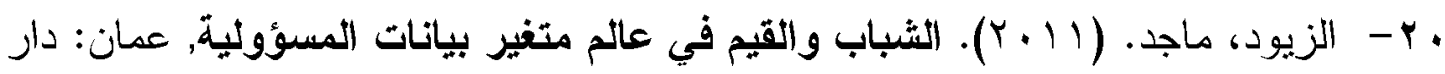

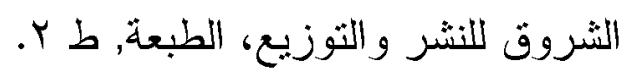

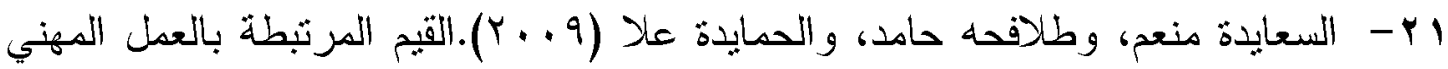

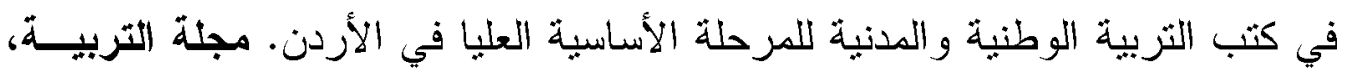

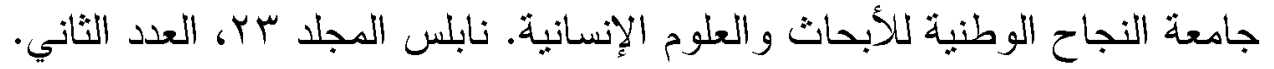




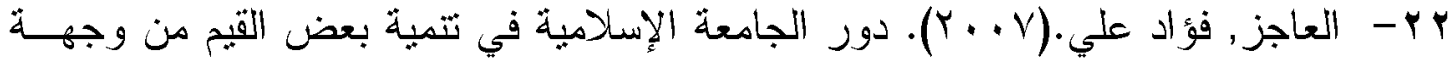
نظر طلبتها، بحث منشور , مجلة الجامعة الإسلامية, سلســة الدراسـات الإنسـانية,

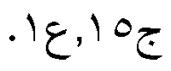

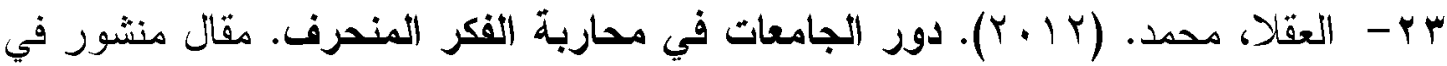

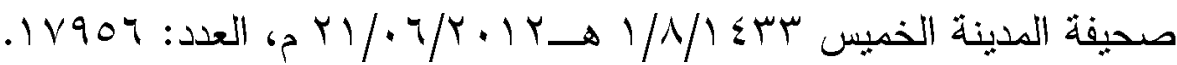

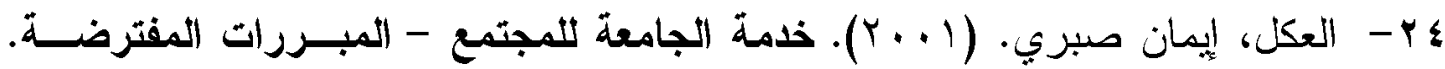
رسالة دكتور اه غير منشورة،كلية التربية، جامعة المنوفية.

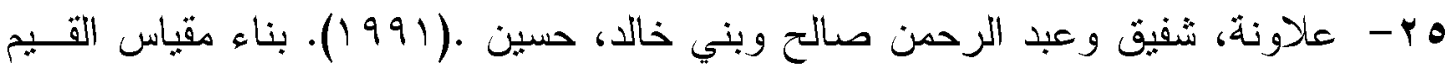

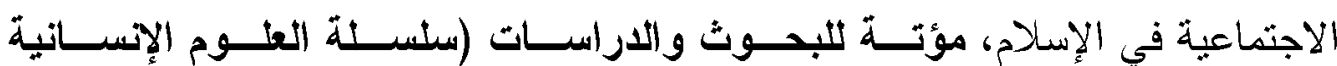
و والاجتماعية). مجلدا .عددس.

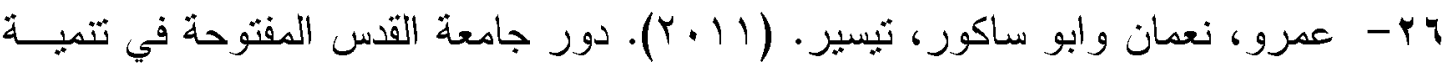

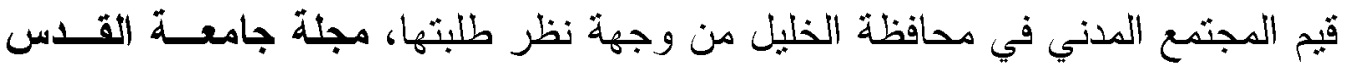
المفتوحة. العدد الثالث و العشرون، المجلد الأول.

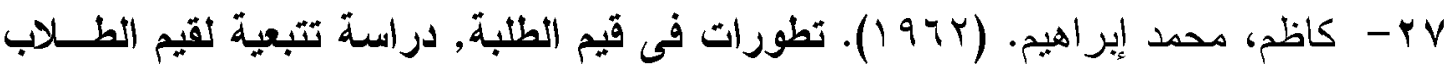

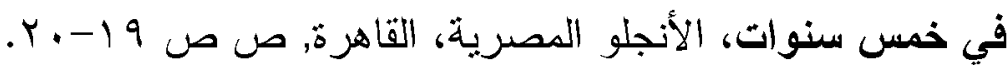

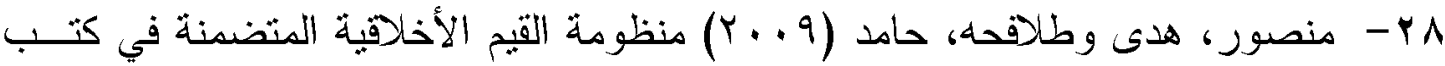

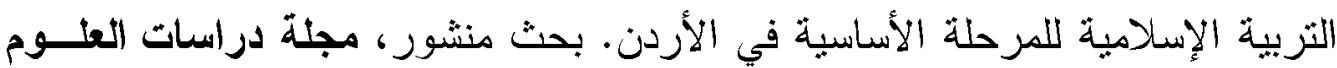
التربوية، عماده البحث العلمي، الجامعة الأردنية، عمان. المجلد سب، العـدد الأول.

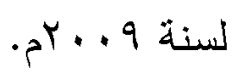

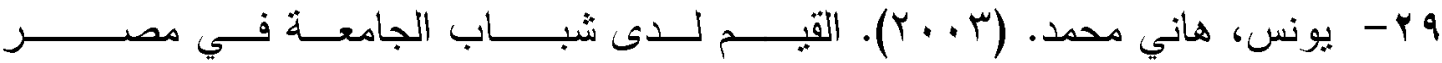
ومتغيرات القرن الحادي والعشرين. مجلة التربية المعاصرة، السنة العشرون، عـدد

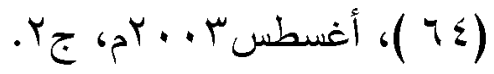

\section{ثانيًا- المراجع الأجنبية:}

30- Johnston, D. Bruce.(2000). The Special Ethical of the Ethical of the Academy .The Review of Higher Education ( $Y$ ) Y r Fall 2000. P.229-236, p. 232 
31- O'Brien, George Danis.(1998). All the Essential Half-Truth about Higher Education. Chicago: The University of Chicago Press, 1998. p. 287.

32- Sinclair, J.M., Collins. (1964). English Dictionary, Third Edition, (Birmingham : Harper Collins Publishers, 1991). 


\section{Abstract}

This study aimed to reveal the role of higher education institutions in the Kingdom of Saudi Arabia to maintain and promote positive values and in the consolidation of the nation's identity, values and cultural heritage and Muslim on the basis of a firm faith in Allah .The study focused on the roles of universities and institutions of higher education in the Kingdom of Saudi Arabia through a range of areas and axes, namely: curriculum and educational programs at hand, and the services and activities provided to the student, legislation and educational goals of the university, and university professor and goals of the university and its policies and philosophy. The methodology used analytical study office and adopted the style of presentation of views in order to offer the greatest possible number of ideas and perceptions on the subject and what enabled us to build our point of view about it.

The study indicated that the universities and other higher education institutions represent a very important socio-cultural learning environment in maintaining the positive values and promotion of the students, and through the experience and knowledge acquired and accumulated by the faculty members and their role in maintaining the values instilled in the hearts of students, along with curriculum and educational programs, education, legislation and the objectives and policies of universities and mission, and it is added to the activities and services provided to students.

Most studies have shown in this area on the significant role of higher education institutions in the province on the positive values and instilled in the hearts of young people. Studies also indicate that Saudi universities provide many positive values and made adequate efforts to maintain the consolidation and promotion of youth have in their scientific and practical. The study made a series of recommendations and proposals for the development of roles and efforts of universities in general and universities in particular Saudi Arabia in order to maintain the values of truth and promote it among its employees of the students and staff. 